\title{
Protektorátní počátky brněnské odbočky Archeologického ústavu
}

\author{
The Protectorate-period roots of the Brno branch \\ of the Institute of Archaeology \\ - Miloš Hlava* -

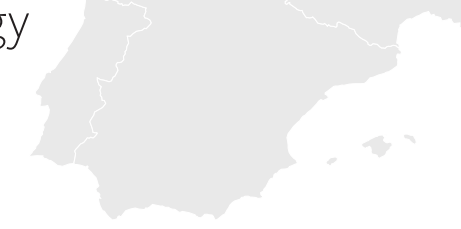

\section{1. Úvod}

\section{KEYWORDS}

History of archaeology - archaeological heritage protection - Institute of Archaeology in Brno - Karl Hucke - Reichsprotektor office

\section{ABSTRACT}

When Karl Hucke assumed the directorship of the Moravian Museum including its Department of Prehistory in November 1941, he very soon attempted to transfer administrative authority over the archaeological heritage care in Moravia from the Institute of Archaeology in Prague in order to take control over Moravian Prehistoric research and to emancipate it from the influence of the Reichsdeutsche archaeologists active in Bohemia. His proposal presented in December of 1941 to the Office of the Reichsprotektor and to the president of Moravia (governor) conceived the transfer of the competences of the Institute of Archaeology to the Department of Prehistory of the Moravian Museum. However, the Reichsprotektor office had no interest in decentralisation of archaeological heritage protection and, therefore, Hucke's proposal ended up being substantially reworked. Based on an idea of a Reichsprotektor office staffer, Wolf von Both, the Brno branch of the Institute of Archaeology was established in the summer of 1942 as a de facto detached institution with some autonomy. Its establishment was therefore a compromise between Hucke's original plan and the effort of maintaining the central role of the Institute of Archaeology as stipulated by the 1941 Government decree on archaeological heritage.

\footnotetext{
* Corresponding author - E-mail address: mihlava@seznam.cz

https://doi.org/10.47382/pv0621-02

Received 31 January 2021; received in revised form 7 March 2021. Available online 30 June 2021.
}

Copyright (c) 2021 Czech Acad Sci, Inst Archaeology Brno, and the authors.

This is an open access article under the CC BY-NC-ND 4.0 license

(https://creativecommons.org/licenses/by-nc-nd/4.0/).

Competing interests: The authors have declared that no competing interests exist.
Samostatný brněnský Archeologický ústav vznikl v roce 1970, avšak jeho organizační počátky jsou o téměř tř̌i desetiletí starší. Byl totiž přímým dědicem, nástupcem a pokračovatelem brněnské pobočky pražského Archeologického ústavu, fakticky detašovaného pracoviště s prvky autonomie, konstituovaného v létě 1942 jako odbočka Brno (Aussenstelle Brünn) tehdejšího Archeologického ústavu (Anstalt für Vor-und Frühgeschichte), založeného v roce 1919 pod názvem Státní archeologický ústav.

Právě brněnská odbočka Archeologického ústavu stojí v centru pozornosti tohoto článku. Ústředním námětem následujících stran je totiž rekonstrukce okolností jejího vzniku a následných organizačních peripetií, jež zažila do jara 1945, tj. během necelých prvních tří let své existence. Naopak takřka zcela opomenuty zůstanou konkrétní terénní a výzkumné aktivity, jimiž se zabývala. Její konstituování ve válečném roce 1942 souviselo s událostmi, jež se v archeologii českých zemí odehrály v důsledku politických a státoprávních změn let 1938 a 1939. Vznik předchůdkyně dnešního brněnského Archeologického ústavu je proto vhodné představit $\mathrm{v}$ širším kontextu - geografickém (tj. neomezeném pouze na moravskou archeologii) i chronologickém (tj. neomezeném pouze na zakládací akt roku 1942). Výkladu o vzniku brněnské odbočky Archeologického ústavu předchází stručné představení organizačního rámce činnosti Státního archeologického ústavu na Moravě a ve Slezsku (především) v meziválečném Československu, jež je neodmyslitelně spojena s Innocencem Ladislavem Červinkou. Je vhodné předeslat, že brněnská odbočka Archeologického ústavu vznikla bez jakékoliv přímé návaznosti na meziválečné Červinkovo působení, jakkoliv některé poválečné stati tuto nezpochybnitelnou skutečnost zastíraly, a to velmi umnými formulacemi (srov. typicky Böhm 1958, 622).

V literatuře věnované dějinám archeologie českých zemí se konstituování brněnské odbočky Archeologického ústavu doposud těšilo pouze minimálnímu zájmu, a totéž platí rovněž o prvních letech její existence (např. Blažek 2003, 587-588, 595-597; Sklenář 2011, 51). Rekonstrukce událostí souvisejících s jejím vznikem v roce 1942 a následných organizačních proměn do jara 1945 je tudíž právě proto založena takřka výhradně na dobových archivních pramenech, resp. (také) na několika textech z poslední doby, které z nich vycházejí (např. Hlava 2020b). Je ovšem třeba upozornit, že k dispozici je (prozatím?) pouhé torzo relevantních archiválií - citelná je obzvláště absence korespondence mezi klíčovými aktéry od závěru ledna do poloviny června 1942. O motivech, jež stály na počátku př́běhu vrcholícího v konstitutivním aktu, však podle mého soudu nelze pochybovat, nebot' jsou v dochovaných pramenech zachyceny v dostatečné míře (k tématu srov. stručně Hlava 2021). 
V této souvislosti poznamenejme, že medailon věnovaný vzniku brněnské odbočky v nedávno vydané knize, jež mapuje stoletou existenci (dnešního) pražského Archeologického ústavu, uvádí, že byla konstituována v roce 1942 jako Centrum výzkumu Velké Moravy (Maříková-Kubková 2019, 74). Toto tvrzení ovšem postrádá jakoukoliv oporu v dobových pramenech.

\section{Innocenc Ladislav Červinka a tzv. konservatorát pro Moravu a Slezsko}

Když byl v průběhu roku 1919 konstituován Státní archeologický ústav jako elitní oborová instituce, jejímž posláním měla být především odborná činnost spojená s prováděním badatelských výzkumů, původní záměr prvního ředitele (a ideového tvůrce instituce) Lubora Niederla počítal s ustavením profesionálních zaměstnanců-prehistoriků, jejichž působení by bylo vymezeno (a zároveň omezeno) geograficky - první tři tzv. státní konzervátoři (Josef Antonín Jíra, Innocenc Ladislav Červinka a Jan Eisner) měli být jmenováni pro jednotlivé části Československa. Niederlova představa však kvůli organizačním zmatkům prvních poválečných let $\mathrm{v}$ ministerstvu školství a národní osvěty, jež bylo zřizovatelem Státního archeologického ústavu, byla de iure naplněna jen zčásti. Jmenovací dekrety, jež ministerstvo vystavilo, byly totiž formulovány odlišně. Jíra byl přidělen Státnímu archeologickému ústavu dekretem z 16. října 1921 (ovšem se zpětnou platností od 1. března 1920), aniž by byl uveden název jeho úředního postavení a vymezeno teritorium. Červinka byl jmenován konzervátorem rovněž bez přesně stanoveného území, a to 8 . července 1920, avšak zároveň mu byla přidělena agenda experta Státního památkového úřadu pro Moravu a Slezsko pro ochranu pravěkých památek, $\mathrm{tj}$. $\mathrm{v}$ této instituci bylo jeho působení teritoriálně přesně vymezeno (srov. Hlava 2020c, 158, pozn. 3). Eisner byl naproti tomu jmenován konzervátorem ministerstva školství a národní osvěty, zároveň byl pověřen „prozatímně úkolem státního konzervátora pravěkých památek pro oblast župy bratislavské, nitranské, svatomartinské, zvolenské, liptovské a košické“1 (srov. Starcová 2020, 138-140). De facto však k rozdělení teritorií došlo u všech tří odborných zaměstnanců Státního archeologického ústavu, neboṫ v praxi Jíra působil v Čechách, Moravu (a Slezsko) měl ve své gesci Červinka a Slovensko bylo vyhrazeno Eisnerovi.

Červinka byl tudíž ustanoven konzervátorem Státního archeologického ústavu bez přesného vymezení teritoria, ovšem ve skutečnosti, a po dohodě s ředitelem Niederlem, působil pouze na Moravě (a ve Slezsku). Ostatně sám Niederle později retrospektivně konstatoval, že „měl vskutku intenci vytvoŕiti $v$ Arch. ústavu oblasti konservatorské pro jednotlivé země. P. Červinka byl sice ministerstvem jmenován konservátorem Arch. ústavu vỉbec, ale ve skutečnosti na základě této intence a praxe mĕl funkci omezenou na Moravu.“2 (srov. Hlava 2020c, 167). Bez ohledu na právní stav Červinka své úřední postavení bez okolků běžně označoval jako konservatorát pro Moravu a Slezsko - a toto hrdé pojmenování používal dokonce např. na úředních tiskopisech, aniž by to v prvním desetiletí jeho práce v dresu Státního archeologického ústavu vyvolalo jakoukoliv negativní odezvu pražské centrály. De iure šlo ovšem o prázdný, byt’ noblesní titul. To se naplno ukázalo v letech 1930-1931 v souvislosti s počínajícími a postupně eskalujícími spory mezi Červinkou a pražským ústředím Státního archeologického ústavu, jež se týkaly principů organizace archeologických výzkumů na Moravě (a ve Slezsku), způsobů přidělování dotací na terénní akce, schvalování ročního plánu výzkumů, priorit badatelských výzkumů před záchrannými akcemi a míry Červinkovy autonomie.
Lubor Niederle i jeho nástupce $\mathrm{v}$ ředitelské funkci Karel Buchtela ponechávali Červinkovi značnou volnost a úřední schvalování (resp. potvrzování) jeho aktivit bylo až do roku 1929 pouze formální. V souvislosti s uvedenými spory a s Červinkovou snahou o zachování zvykového statu quo však přišlo v roce 1931 na př̀etřes kromě dosavadní tolerované praxe také prověřování přesného oficiálního znění jeho konzervátorského pověřní. Jaroslav Böhm, jenž od konce 20. let 20. století začínal ve Státním archeologickém ústavu výrazně vystupovat do popředí, tehdy pro domo poznamenával, že podle ministerského dekretu z 8. července 1920 je Červinka vskutku obecně „,konservatorem Čsl. St. A. Ú v Praze' a mimo to byla jemu pridělena agenda experta ochrany památek pro Moravu a Slezsko. (...) Není tudíž žádný,konservatorát pro Moravu a Slezsko"“3(srov. Hlava 2020c, 166-167). A sám Niederle k tomu retrospektivně v roce 1933 poznamenával: „Nemůže býti tedy řeči o nějaké úplné samostatnosti v řízení výzkumů na Moravě.“" Praktický důsledek těchto závěrů spočíval v nepokrytých výhrůžkách Červinkovi, že bude přeložen do Prahy bez ohledu na jeho celoživotní sepětí s moravskou archeologií. Šlo jednoznačně o nátlak a naznačení způsobu potenciální odvety za Červinkovo jednání, jež bylo v Praze považováno za neloajální. Červinka totiž ve sporu s pražským ústředím neváhal podnikat kroky za zády vedení Státního archeologického ústavu, včetně např. samostatné komunikace s nadřízeným ministerstvem školství a národní osvěty. V září 1931 dokonce navrhl rozdělení Státního archeologického ústavu na dvě samostatné instituce - pro Čechy a pro Moravu (podrobněji Hlava 2020c).

Když Červinka odešel v polovině roku 1937 do penze, jeho tabulkové místo konceptního úr̆edníka v hodnostní třídě komisaře správní osvětové služby zůstalo neobsazeno. Jelikož ředitel Buchtela zastavil Červinkovi v roce 1931 dotace na terénní aktivity, badatelské výzkumy na Moravě (popř. ve Slezsku) byly od té doby organizovány přímo z pražského ústředí, a navíc jich nebylo mnoho - nejvýznamnějším byl bezesporu interdisciplinární výzkum laténského oppida Staré Hradisko v letech 1934-1937. Záchranných výzkumů se ujalo prehistorické oddělení Moravského zemského muzea pod záštitou Josefa Skutila (a od března 1934 za aktivní účasti Josefa Poulíka). A po zkušenostech s Červinkou nebyla v pražském ústředí Státního archeologického ústavu zjevně ani vůle tento stav jakkoliv změnit. S potenciálními Červinkovými nástupci se tudíž nepočítalo pro Moravu (a Slezsko) - primárně měli působit v pražském ústředí bez jakéhokoliv bližšího teritoriálního vymezení své činnosti. Ostatně s centralizací činnosti ve Státním archeologickém ústavu souvisel nepochybně také odchod Jana Eisnera z konzervátorského postu na konci roku 1936 (Starcová 2020, 140). Od ledna 1937 se Eisner stal jednatelem Státního archeologického ústavu pro několik politických okresů na jihozápadním Slovensku, tj. fakticky regionálním spolupracovníkem instituce, v níž byl dříve zaměstnán (Hlava 2020a, 25, tab. 3).

Vhodným kandidátem na uprázdněnou pozici byl původně Rudolf Turek, zaměstnaný ve Státním archeologickém ústavu jako volontér v letech 1935-1936. V době Červinkova penzionování však vykonával vojenskou službu a po jejím skončení byl ustanoven prozatímním profesorem na gymnáziu ve Spišské Nové Vsi na Slovensku. ${ }^{5}$ O systemizované místo po Červinkovi se poté ucházel Ivan Borkovský, jehož provizorní postavení při výzkumu Pražského hradu (kde působil od dubna 1926) a způsob financování jeho mzdy se staly od roku 1936 předmětem licitace mezi Nejvyšším účetním kontrolním úřadem, Kanceláří prezidenta republiky a Státním archeologickým ústavem. Svoji žádost podal k ministerstvu školství a národní osvěty 2 . března $1938 .{ }^{6}$ Po zdlouhavých úředních peripetiích a úsporných rozpočtových opatřeních Kanceláře prezidenta republiky na rok 1939, jež byly 
pro Borkovského neodvratnou předzvěstí brzkého konce dosavadní praxe, mu nakonec bylo přiděleno tabulkové místo nikoliv po Červinkovi, ale po Vojtechu Budavárym, který se na počátku roku 1939 vrátil na Slovensko a od 1. března 1939 stál v čele tamějš́iho nově konstituovaného Štátneho archeologického ústavu (Neumann 2019, 12-13). Borkovský byl ve Státním archeologickém ústavu ustaven vědeckou pomocnou silou ministerským dekretem z 22. dubna 1939, ovšem se zpětnou platností k 1. lednu 1939 (srov. nepřesně Hlava 2019, 422).?

Volné místo po Červinkovi bylo nakonec 17. června 1939 přiděleno Václavu Menclovi, působícímu až do dubna 1939 na Slovensku v tamějším Štátnom referátu na ochranu pamiatok $\mathrm{v}$ Bratislavě; rovněž v tomto případě bylo jmenování provedeno se zpětnou platností, tentokráte k 1 . květnu $1939 .{ }^{8}$ Ve Státním archeologickém ústavu se měl věnovat výzkumům v trase plánované dálnice Praha-Brno-Zlín, projektu soupisu hradišt v českých zemích, jehož součástí bylo také zaměřování nalezišrt', a grafickému zpracování rozsáhlých výzkumů z předchozích let, mezi nimiž nechyběly ani výzkumy na Moravě - na Starém Hradisku a ve Starém Městě u Uherského Hradiště. ${ }^{9}$ Již v březnu 1940 ale odešel na ministerstvo školství a národní osvěty (Hlava 2019, 425), aniž by za něho byla k dispozici náhrada.

Státní archeologický ústav se tudíž potýkal s výraznou personální nouzí a přes opakované žádosti o navýšení tabulkového stavu zaměstnaneckých míst (a příslušných finančních prostředků), jež byly neúnavně směrovány na nadřízené ministerstvo školství a národní osvěty, zůstávala situace až do roku 1939 kritická. Jak ale ukázaly peripetie spojené s obsazením místa po Červinkovi, problém spočíval primárně v nedostatku vhodných adeptů s profesionálním vzděláním v oboru. V dubnu 1939 (tj. ještě před př́íchodem Václava Mencla) pracovalo ve Státním archeologickém ústavu pouhých šest zaměstnanců, z toho jen dva prehistorikové s univerzitním vzděláním - Jaroslav Böhm a Ivan Borkovský. Jakkoliv během následujících měsíců roku 1939 nastala změna a Jaroslavu Böhmovi, který stál od přelomu února a března 1939 v čele instituce, se podařilo získat zaměstnance pro technické zázemí ze zrušených ministerstev a organizací, profesionálních prehistoriků bylo stále málo (blíže Hlava 2019, 421-424, obr. 4). Když ale na počátku roku 1940 zformuloval ambiciózní výzkumný program, nechyběly v něm ani lokality z Moravy a Slezska (Hlava 2017, 23, 32-36). Ve výčtu čtrnácti konkrétních míst, na nichž měl výzkum proběhnout v roce 1940, moravské lokality dokonce převažovaly (Hlava 2017, 35). Realita nových protektorátních poměrů se však již také v archeologii hlásila neúprosně o slovo a Böhmův impozantní výzkumný plán doznal v praxi výrazných změn. Na výzkumy na Moravě se nedostávalo času, sil ani prostředků nejen $\mathrm{v}$ roce 1940, ale ani v roce 1941.

\section{Brněnská odbočka Archeologického ústavu}

Když byl v polovině března 1939 vytvořen Protektorát Čechy a Morava z vůle (a pod záštitou) Německé říše s proponovanou (ovšem v praxi naprosto iluzorní) autonomií, bylo zřejmé, že převratných změn nebudou ušetřeny ani zdejší české vědecké a kulturní instituce. Platilo to rovněž o archeologii a jejích organizačních strukturách. Národnostně česká archeologie se prakticky okamžitě stala předmětem zájmu říšskoněmecké archeologie.

\subsection{Situace v protektorátní archeologii}

V diskusích během prvních protektorátních týdnů o nejvhodnějším postupu hráli dominantní roli úředníci ř́šského ministerstva vědy, výchovy a vzdělávání v Berlíně (především Werner Buttler a Robert Hiecke) a od poloviny dubna 1939 také
Úřadu ř́išského protektora v Praze (především Hans Reinhold, který do Prahy přišel právě z uvedeného ministerstva). Již na konci jara 1939 vykrystalizovaly jasné obrysy celkového plánu.

$\mathrm{V}$ zásadě byly stanoveny tři hlavní principy, resp. cíle: (1) ústředním (badatelským) pracovištěm říšskoněmecké prehistorie v Protektorátu Čechy a Morava měla být univerzita, zcela v souladu s poměry obvyklými v Německé ř́ísi, (2) do tří nejvýznamnějších oborových pracovište - Státního archeologického ústavu, Národního muzea a Moravského zemského muzea - měly být dosazeny německé odborné síly do pozic zástupců vedoucích (tj. nikoliv na ředitelská místa) kvůli získání kontroly nad činností institucí a efektivního využití jejich odborného i osvětového potenciálu, (3) terénní i teoretický výzkum měl být zaměřen na germánský pravěk. Cílem tudíž nebyla destrukce stávajícího stavu či institucí, ale jejich usměrnění a ovládnutí, a to s minimalistickým vynaložením prostředků - rovněž říšskoněmecká archeologie se totiž potýkala s personální nouzí, třebaže výuka prehistorie na říšskoněmeckých univerzitách zažívala v 30. letech 20. století velký rozmach (Pape 2002, 166-175, Abb. 3-20).

Speciální pozornost nových mocipánů patřila Státnímu archeologickému ústavu. V meziválečném Československu se těšil výsostnému postavení badatelské instituce. Nyní měl být přetvořen v organizaci provádějící především záchranné výzkumy, a to podle modelu osvědčeného v řadě částí Německé ŕíše. Instituce specializovaná na záchrannou terénní činnost a archeologickou památkovou péči totiž v českých zemích neexistovala - v rámci svých aktivit ji po dohodě se Státním archeologickým ústavem zčásti suplovala obě ústřední muzea (Národní muzeum, Moravské zemské muzeum), zčásti tyto povinnosti spadaly do gesce Státního památkového úřadu pro Čechy a Státního památkového úrradu pro Moravu a Slezsko. Šlo ale spíše o nahodilé zásahy na narušených nalezištích, o nichž se úřední místa shodou okolností dozvěděla. To ovšem souviselo s absencí památkového zákona, jenž by stanovil jasná pravidla a principy ochrany nalezišt', resp. náhodných nálezů. Krok vpřed nepochybně znamenalo ustavení jednatelů Státního archeologického ústavu v roce 1935 s pětiletým funkčním obdobím, v podstatě regionálních spolupracovníků, kteří měli pražské ústředí informovat o narušených archeologických nalezištích a v př́ípadě potřeby (ovšem se souhlasem Státního archeologického ústavu) provádět drobné záchranné akce v přidělených územích; v porovnání se sousední Německou řriší šlo ovšem pouze o skromný počin s výrazně nižší efektivitou (Hlava 2020a, 16-24, 29, tab. 1-3).

Přes dalekosáhlé plány byla situace německé archeologie v Protektorátu Čechy a Morava na jaře 1939 naprosto tristní prehistorické pracoviště na pražské Německé univerzitě nebylo obsazeno a v prehistorických odděleních dvou nejvýznamnějších muzeí nebyl zaměstnán žádný prehistorik německé národnosti. Ostatně jediným prehistorikem německé národnosti ve třech nejvýznamnějších archeologických institucích meziválečného Československa byl Anton Gnirs, zaměstnaný v letech 1925-1933 ve Státním archeologickém ústavu jako konzervátor pro antické památky. Primární snahou bylo tudíž obsazení uprázdněného univerzitního pracoviště, na něž byl v září 1939 povolán Lothar Zotz. Až do léta 1941 se stal nejdůležitějším (ovšem zároveň také jediným profesionálním!) německým prehistorikem v protektorátní archeologii, avšak jeho moc rozhodně nebyla neomezená. Ústřední role v personálních i obecných koncepčních záležitostech totiž příslušela Úřadu říšského protektora, v němž archeologické záležitosti spadaly do kompetence Hanse Reinholda. Jakkoliv Lothar Zotz a Hans Reinhold dokázali úspěšně kooperovat, konečné rozhodnutí nepříslušelo Zotzovi. Ten sice mohl přicházet $\mathrm{s}$ náměty a návrhy, avšak v zásadních věcech neměl poslední slovo. 


\subsection{Klíčový faktor: nečekané změny v Moravském zemském muzeu}

Vznikající německé plány jednotného postupu podle stanovených principů byly hned na počátku narušeny změnami, jež se odehrály $\mathrm{v}$ Moravském zemském muzeu. Z podnětu místních Němců a za asistence gestapa byl totiž již 16. března 1939 z čela muzea odstraněn český ředitel Jaroslav Helfert a na jeho místo byl jako komisařský správce instalován Josef Freising, jeden z německých národoveckých vlastivědných badatelů. Šlo o odvetu za události, jež se za Helfertova výrazného přispění odehrály po roce 1918 a vedly k odstranění německého vlivu na chod instituce bez jakéhokoliv ohledu na platné stanovy Moravské muzejní společnosti, která tehdy muzeum spravovala.

V pražském ústř̌edí Úřadu říšského protektora se o událostech v Brně dozvěděli teprve na počátku června 1939 a přijali je s velkými rozpaky. S kritikou (nejen) ze strany německých úředních míst se setkaly rovněž Freisingovy diletantské způsoby jednání v jeho nové funkci, a tak v létě 1939 bylo v Praze rozhodnuto, že bude nahrazen kvalifikovanou odbornou silou. Třebaže zprvu byla ve hře varianta s národnostně českým ředitelem a jeho německým zástupcem, nakonec bylo z prestižních důvodů upřednostněno ponechat ředitelskou funkci $\mathrm{v}$ německých rukách. Výběr vhodného adepta, jenž měl mít vzhledem k charakteru muzejních sbírek prehistorické či př́rodovědné vzdělání, se ale protáhl. První dva návrhy z léta 1939 Friedrich Behn (z Ř́msko-germánského centrálního muzea v Mohuči) a Eduard Beninger (z Př́rodovědeckého muzea ve Vídni) - nepřekročily rámec zákulisních úvah a interních diskusí. To samé platilo také o Adolfu Mahrovi (bývalém řediteli Irského národního muzea v Dublinu). Reálnější byly dvě další možnosti, tentokráte z dubna 1940 - Lothar Zotz doporučil Karla Huckeho (zaměstnaného v Zemském úřadu pro pravěk ve Vratislavi), současně se z vlastní iniciativy ucházel o ředitelské místo Hermann Stoll (zaměstnaný v Zemském úřadu pro pravěk a ranou dobu dějinnou ve Freiburgu). Klíčové nakonec byly posudky na oba kandidáty, jež nechal v létě 1940 vypracovat Hans Reinhold. Výrazně úspěšněji jimi prošel Karl Hucke. Všechna poskytnutá vyjádření byla totiž bezvýhradně kladná a shodně zdưrazňovala především jeho organizační schopnosti. V Praze tudíž měli o novém řediteli Moravského zemského muzea jasno na přelomu léta a podzimu 1940 (k výběru ředitele Moravského zemského muzea podrobně Hlava 2020b, 312-320). Svojí troškou do mlýna přispěla dodatečně také Bezpečnostní služba (Sicherheitsdienst) - rovněž její vyjádření o Huckem byla jednoznačně pozitivní (obr. 1). ${ }^{10}$

Karl Hucke pocházel z Berlína, kde spatřil světlo světa 7. června 1911. Po maturitě na gymnáziu studoval od roku 1930 prehistorii, geologii a antropologii na univerzitách v Marburgu, Berlíně a Kielu, kde v roce 1935 promoval. Po krátkém působení př̀ archeologickém výzkumu v trase říšské dálnice HamburgLübeck pracoval od začátku roku 1936 v Zemském muzeu pro pravěk a ranou dobu dějinnou ve vestfálském Münsteru. Od 1. listopadu 1938 byl zaměstnán v Zemském úřadu pro pravěk v dolnoslezské Vratislavi. Nepochybná odborná erudice šla u něj ruku v ruce s ideovou pevností. Hucke již 1. června 1931 vstoupil do NSDAP a o měsíc dř́ve se stal také členem SA. Byl rovněž spolupracovníkem stranické Bezpečnostní služby a udržoval kontakty s Výzkumnou a učenou společností „Dědictví předkü“ (Forschungs- und Lehrgemeinschaft „Das Ahnenerbe“), „badatelskou“ organizací SS, založenou v roce 1935 pod záštitou ř́šského vůdce SS Heinricha Himmlera. Jeho kádrový profil byl tudíž bez poskvrny (obr. 2). ${ }^{11}$

\subsection{Cesta ke konstituování brněnské odbočky Archeologického ústavu}

Na konci záŕí 1940 oznamoval Hans Reinhold důvěrně Karlu Huckemu, že s jeho povoláním do Brna souhlasil Karl Hermann Frank, státní tajemník v Úřadu ř́íšského protektora. ${ }^{12}$ Avšak cesta k jeho instalování do Moravského zemského muzea byla ještě dlouhá. Hucke byl totiž pro svoji novou roli vyhlédnut a vybrán bez vědomí svých nadřízených. Jelikož byl od 1. listopadu 1938 zaměstnán v dolnoslezském Zemském úřadu pro pravěk ve Vratislavi, byl de iure zaměstnancem provincie Slezsko. Navíc na počátku války v září 1939 vstoupil jako dobrovolník do wehrmachtu a po nezbytném výcviku byl v květnu 1940 nasazen se svojí jednotkou v tažení proti Francii na západní frontě. Uvolnění ze zemských služeb proběhlo bez větších komplikací (byt nikoliv bez prvotní negativní odezvy ze Slezska) k 31. květnu 1941, a tak byl Hucke k 1. červnu 1941 oficiálně jmenován novým ředitelem Moravského zemského muzea. Jeho příchod do Brna však stále nebyl na pořadu dne. Vyjednávání s wehrmachtem bylo totiž mnohem obtížnější. Dosáhnout uvolnění zdravého třicetiletého rekruta s bojovými zkušenostmi nebylo snadné, navíc Huckeho jednotka se na jaře 1941 opět zapojila do válečných operací, tentokráte na jihovýchodě Evropy. ${ }^{13}$ Klíčové nakonec bylo Huckeho přeřazení z bojové do záložní jednotky, k němuž došlo ze zdravotních důvodů v létě 1941 po návratu do střední Evropy. ${ }^{14}$ Teprve poté, v průběhu ř́jna 1941, byl Hucke z armády uvolněn, ${ }^{15}$ zprvu však pouze do 15 . ledna 1942. Povolení, jímž byl dočasně zproštěn vojenské služby, muselo být tedy neustále prodlužováno a výsledek žádosti byl pokaždé nejistý. ${ }^{16}$

Svých povinností v novém působišti se Hucke chopil teprve 11. listopadu 1941. Třebaže od léta 1940 byl v trvalém spojení s Hansem Reinholdem z Úřadu ř́íského protektora (a od května 1941 s jeho nástupcem Wolfem von Bothem), o situaci v Moravském zemském muzeu a moravské archeologii získal patrně jasnou představu teprve přímo v Brně - šlo přitom nejen o řízení celého muzea, ale také o situaci v tamějším prehistorickém oddělení a plány s Ústavem Anthropos, budovaným jako elitní pracoviště pro výzkum paleolitu. V dochované korespondenci z doby Huckeho vojenské služby ve wehrmachtu není přitom ani slovo o potenciálních plánech v oblasti archeologické památkové péče, avšak to může mít jednoduchou příčinu - až do léta 1941 neexistoval pro území Protektorátu Čechy a Morava žádný památkový zákon, jenž by jasně kodifikoval pravidla a povinnosti jednotlivců i institucí, a do podrobností jeho př́ípravy Hucke žrejmě zasvěcen nebyl, jakkoliv prvotní podnět $\mathrm{k}$ jeho vytvoření vzešel v létě 1940 od Lothara Zotze, s nímž Hucke setrvával v kontaktu. Vládní nařízení o archeologických památkách bylo schváleno v červnu 1941 (v platnost vstoupilo teprve v červenci 1941, kdy bylo úředně zveřejněno). Zakotvilo ústřední pozici Archeologického ústavu při povolování výzkumů a jejich provádění, zároveň ovšem pamatovalo také na Zemské úřady - právě jim totiž podle jednoho z ustanovení (paragraf 3, odstavec 2) př́slušela v obvodu jejich působnosti ochrana archeologických památek (k vládnímu nařízení o archeologických památkách viz např. Blažek, Lutovská 2002; Sklenář 2011, 52, 100-101). Právě disproporčně stanovených pravomocí dvou Zemských úřadů a jednoho Archeologického ústavu se Hucke pokusil využít.

Tři dny po svém příchodu do Brna sděloval do Prahy Wolfu von Bothovi své první dojmy z nového prostředí: „Dabei ergeben sich für mich sehr viele Fragen, die nicht allein das Landesmuseum sondern auch das Anthropos-Museum und auch die vorgeschichtliche Denkmalpflege betreffen, sodass ich es für angebracht halte, Ihnen die den Bereich des Landes Mähren überschreitenden Probleme persönlich vorzutragen." Avizoval, že po polovině listopadu zavítá do 


\section{Der Fithret Deg g0-Leitab/dhnitts Drag}

PA 3572 - I
Prag-Bubentich

An den

Herrn Unterstaatssekretär

Dr. von $B$ u $r$ s d o $r f$

Prag

Betr.: Dr. Karl H u c k e, Kustos am Landesamt für ,Vorgeschichte in Breslau

Anlg.: 1 Originalvorgang

Die angestellten Ermittlungen über Dr. Karl $\mathrm{H} \mathrm{u} c \mathrm{k} e$ hatten ein positives Ergebnis.

$\mathrm{H} \mathrm{u} \mathrm{c} \mathrm{k}$ e ist Studienkollege des mir persönlich bekannten Professors $J$ a $n \mathrm{k} u \mathrm{~h}$, Kiel, dem Leiter der 4h-Grabung Haithabu bei Schleswig. Hucke wurde später durch Jankuhn stärkstens gefördert. Vor seinem Amtsantritt in Schlesien war er drei Jahre in Münster i.Westfalen tätig, konnte sich jedoch dort in der stark katholischen Umgebung nicht halten und wurde von Dr. $P$ e $t$ e $r$ e $n$ nach Breslau geholt. Er ist verheiratet und hat zwei Kinder. Es werden gegen ihn keine Bedenken erhoben. Er gilt in weltanschaulicher Hinsicht als vollkommen gefestigt.

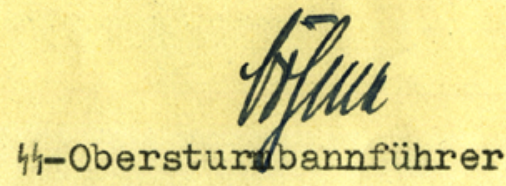

Obr. 1. Vyjádření Bezpečnostní služby o Karlu Huckem z22. listopadu 1940.

Národní archiv (dále NA), fond Úřad říšského protektora v Čechách a na Moravě, sign. 114-197/2, karton 195 (nezpracovaná část).

Fig. 1. The Sicherheitsdienst assessment on Karl Hucke, dated 22 November 1940.

National Archives (hereinafter referred to as NA), collection Reichsprotektor Office in Bohemia and Moravia, sign. 114-197/2, box 195 (unprocessed part). 
Protektorátní počátky brněnské odbočky Archeologického ústavu •

- Přehled výzkumů 62/1, 2021

$149-166$

Enbunstaing num touguonis thr nifupfaftlighe

18

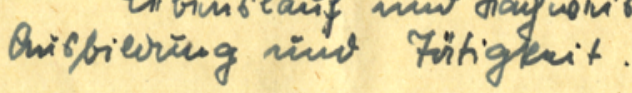

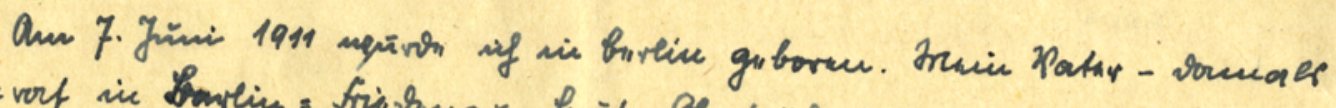

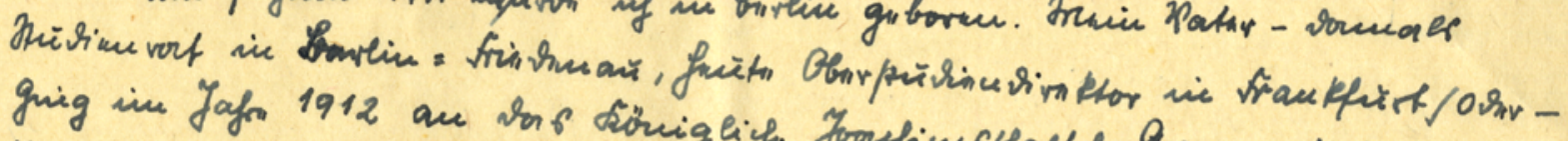

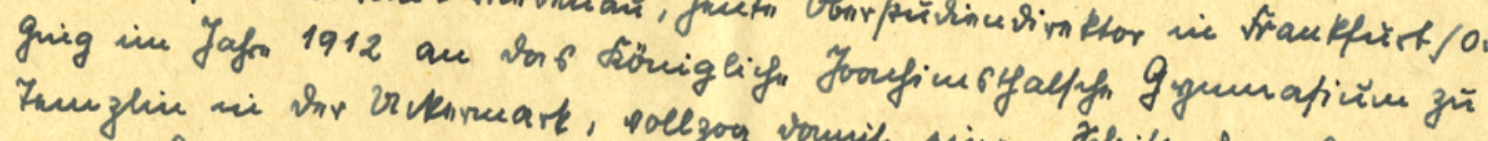

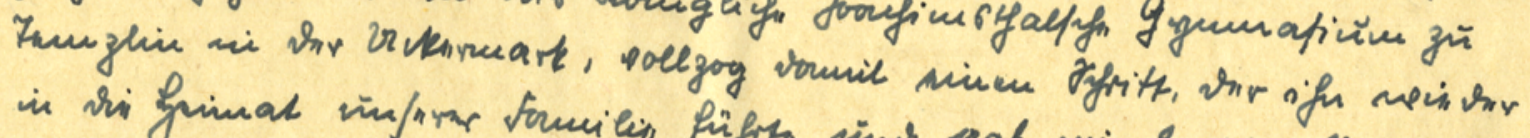

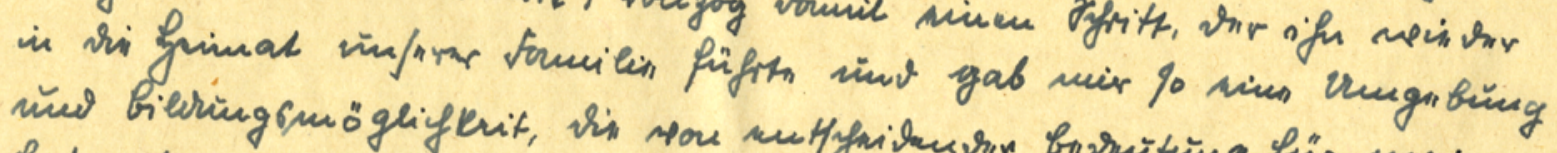

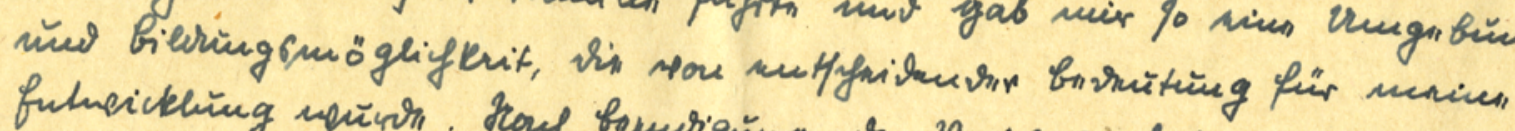

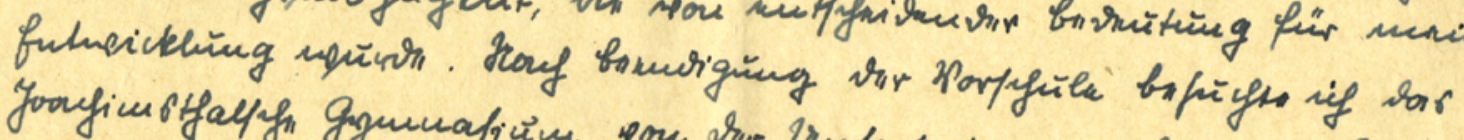

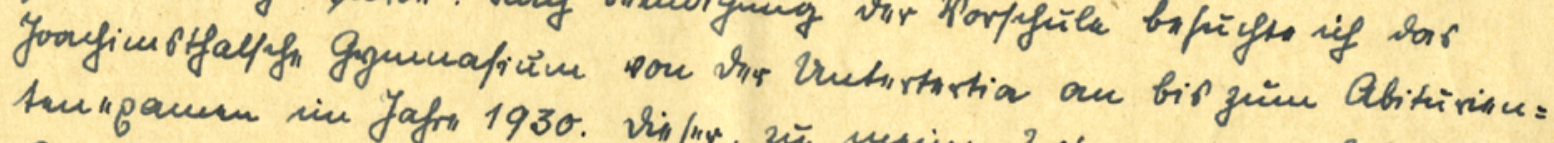

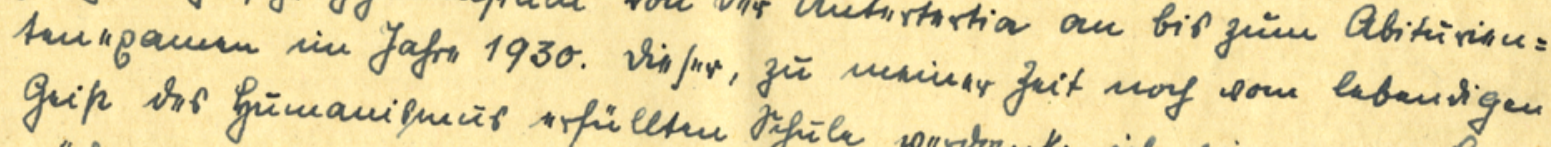

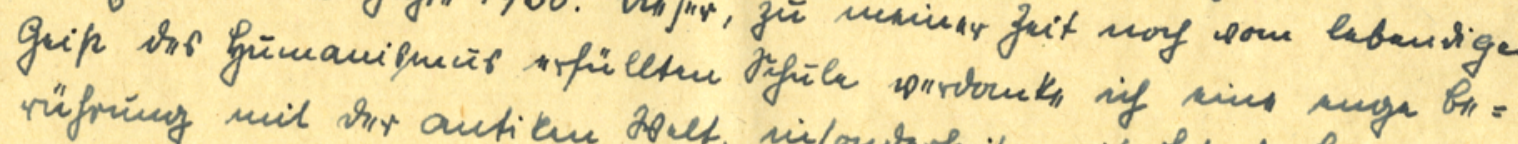

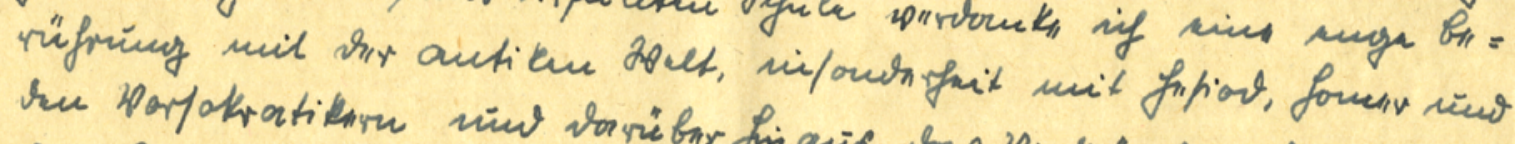

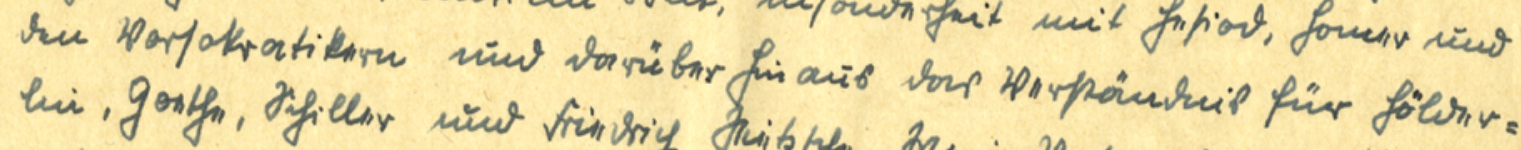

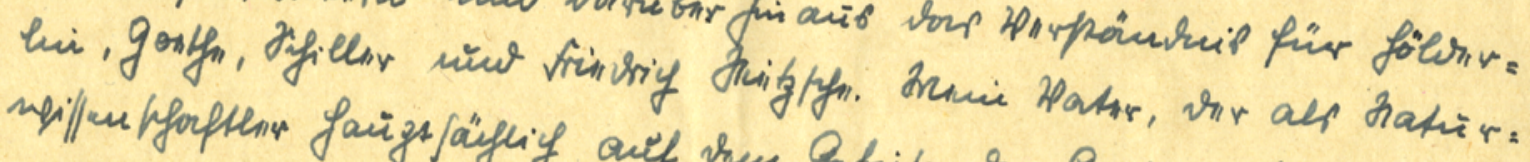

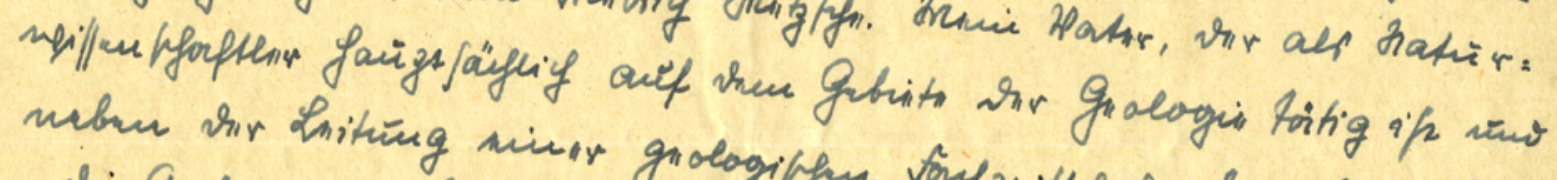

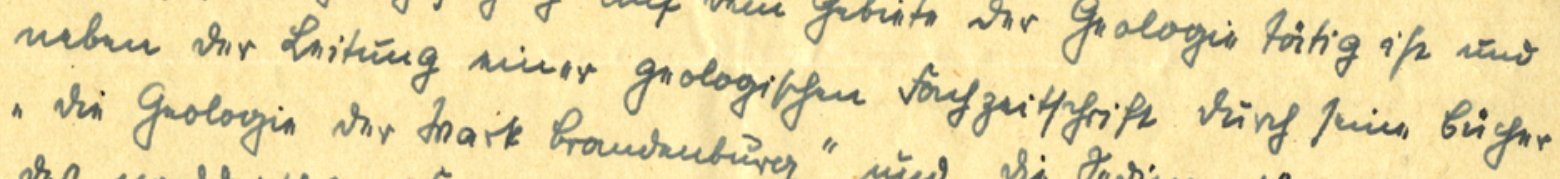

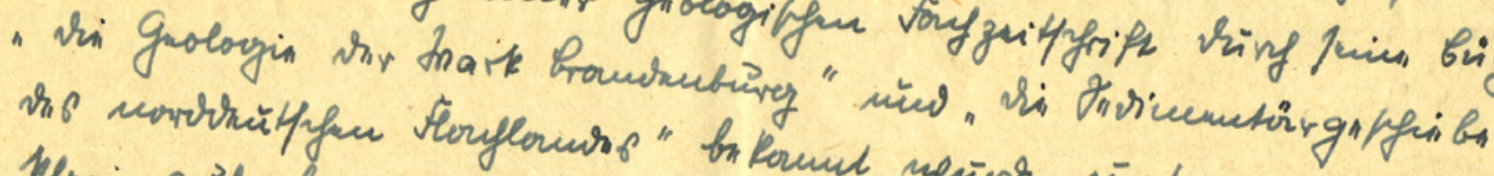

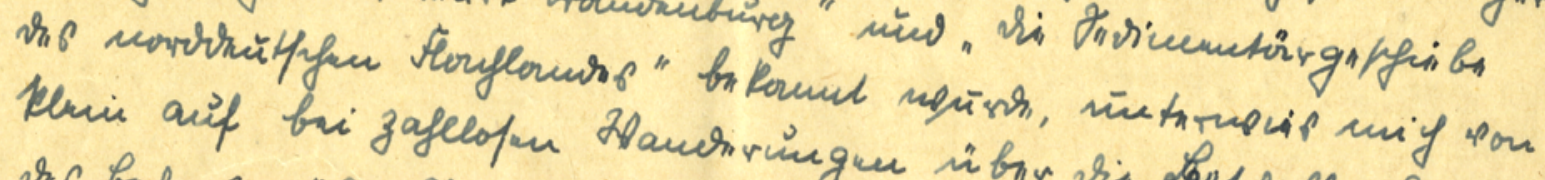

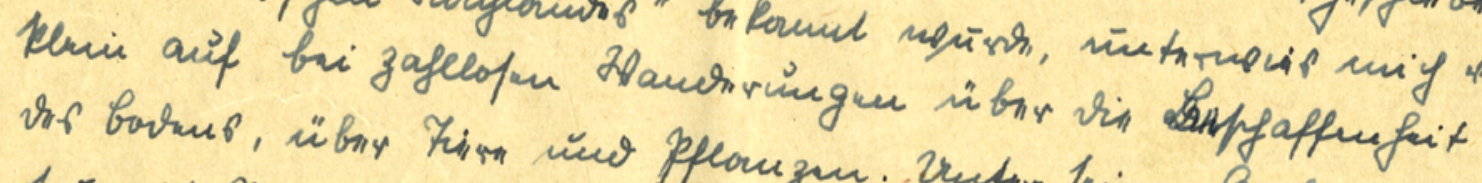

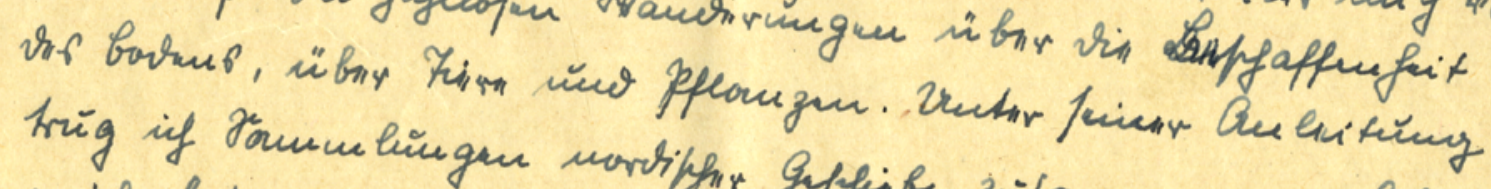

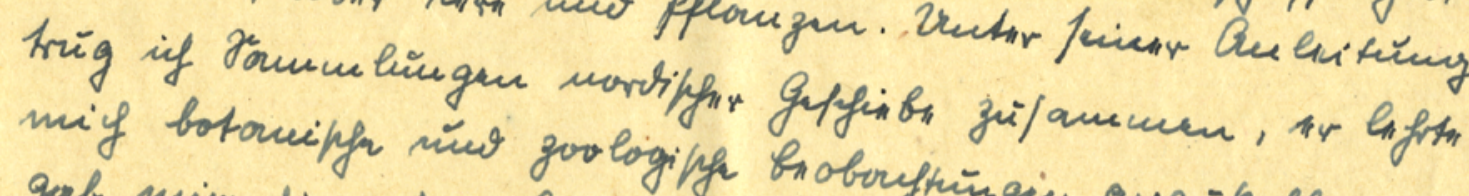

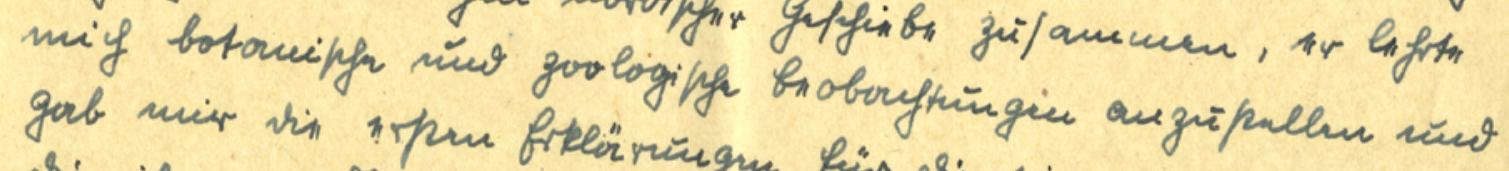

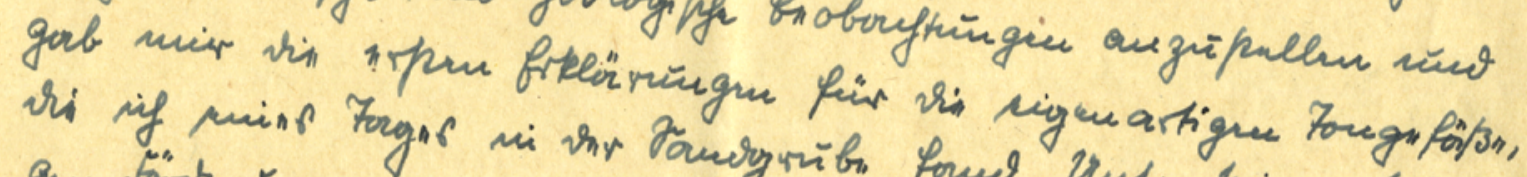

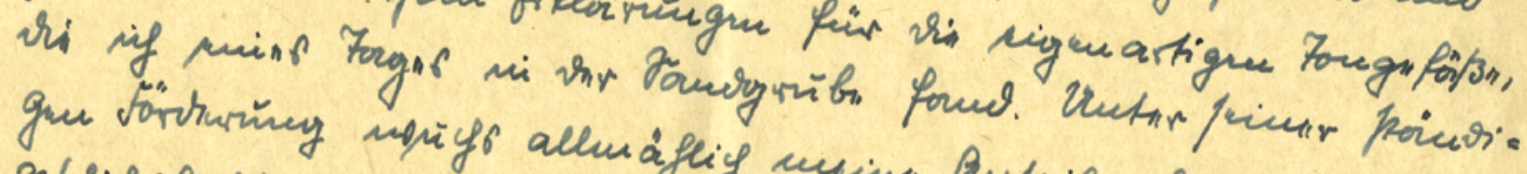

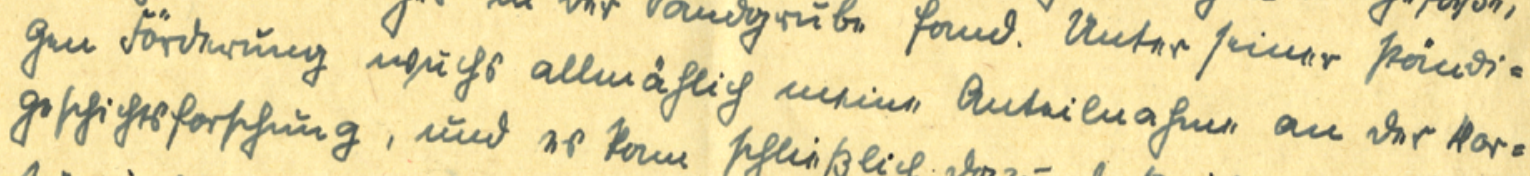

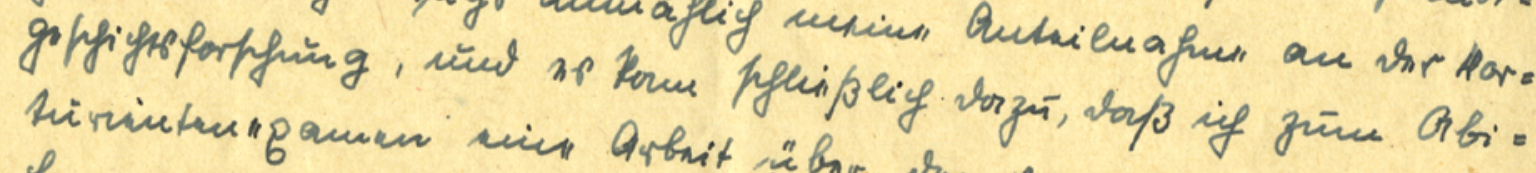

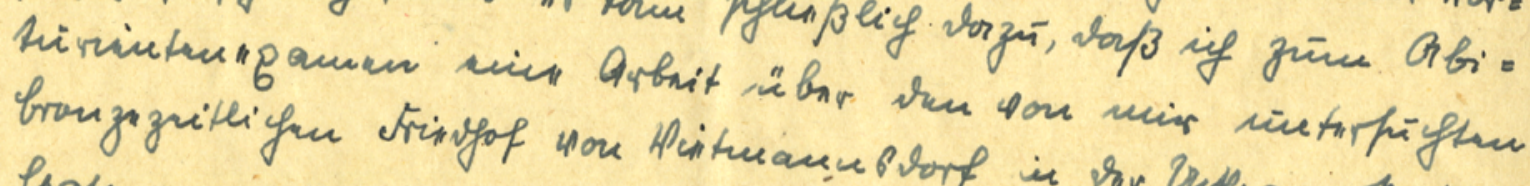

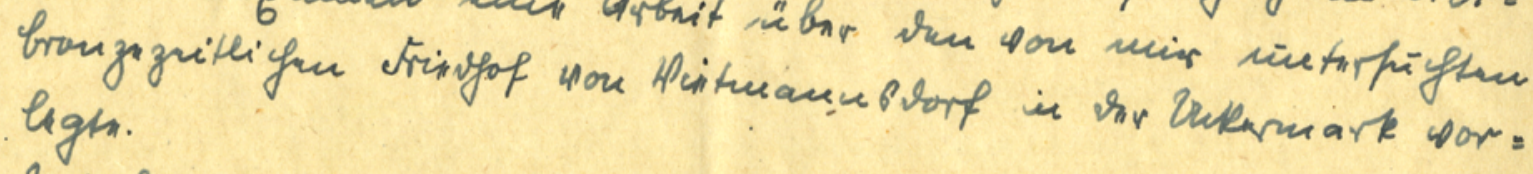
ligh.

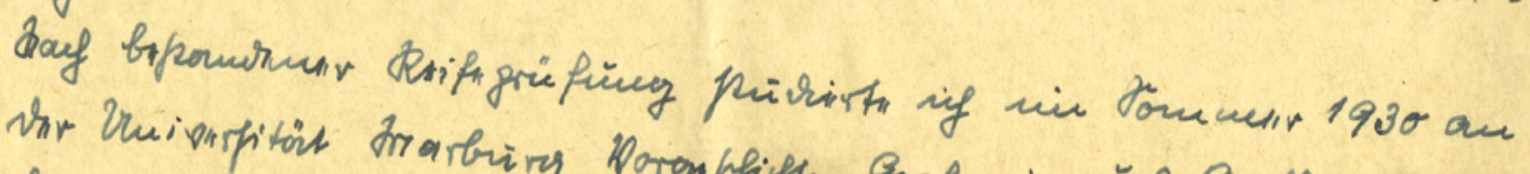

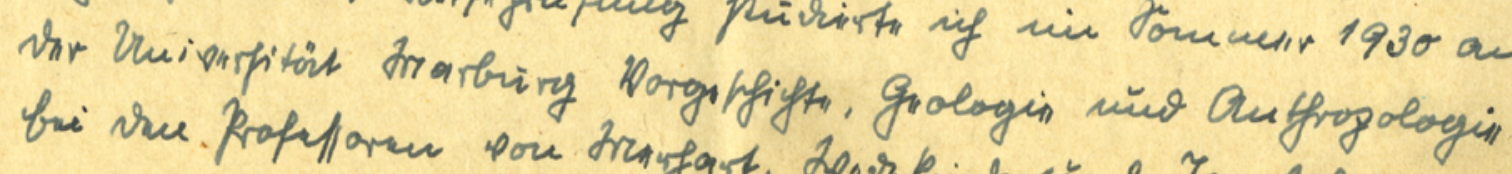

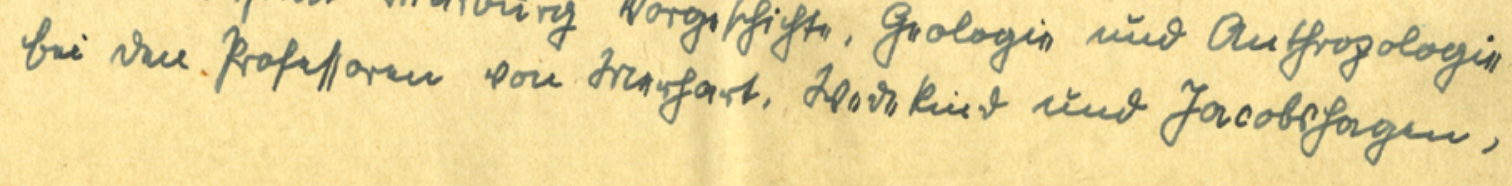

154 
Prahy kvůli diskusím s Lotharem Zotzem, a proto von Bothovi navrhoval, že by této př́ležitosti mohli rovněž využít $\mathrm{k}$ rozhovoru. ${ }^{17}$ Ke schůzce mezi Huckem a von Bothem patrně skutečně došlo - s největší pravděpodobností se odehrála 20. listopadu 1941, aniž by bylo možné zjistit jakékoliv podrobnosti o jejím obsahu. ${ }^{18}$ Je ale takřka jisté, že se na ní diskutovalo (také) o archeologické památkové péči na Moravě.

Zřejmě právě v reakci na listopadová jednání v Praze vypracoval Hucke obsáhlý rozklad o stavu archeologické památkové péče na Moravě a 12. prosince 1941 jej zaslal jednak moravskému zemskému viceprezidentovi Karlu Schwabemu (tj. v institucionální a úřední hierarchii svému nadřízenému, nebot Moravské zemské muzeum bylo zemskou institucí), jednak Úřadu říšského protektora. Nejdůležitější pasáž se nacházela na samém konci elaborátu - Hucke navrhoval převedení pravomocí v oblasti archeologické památkové péče pro Moravu z Archeologického ústavu na prehistorické oddělení Moravského zemského muzea (obr. 3). Argumentoval vcelku logicky - za posledních osm let provádělo naprostou většinu terénních akcí na Moravě právě Moravské zemské muzeum („So führte die Abteilung Urgeschichte am Mährischen Landesmuseum in den Jahren 1934-1941 insgesamt 62 grössere, auf die Bergung vorgeschichtlicher Funde gerichtete Ausgrabungen durch, an denen die Anstalt für Vor- und Frühgeschichte in Prag in nur 3 Fällen beteiligt war.“), tj. v zásadě by šlo pouze o kodifikaci reálného stavu. Uvedl také konkrétní př́íklady spojení archeologické památkové péče s muzejními institucemi v Německé říši. Zmínil rovněž vzorový příklad decentralizované archeologické památkové péče ve Slezsku. Zde totiž v rámci jedné země (provincie Slezsko) existovaly dvě samostatné instituce, jež působily v odlišných regionech - Zemský úřad pro pravěk $\mathrm{v}$ dolnoslezské Vratislavi a Zemský úřad pro pravěk v hornoslezské Ratiboři. Huckeho návrh také řešil kompetenční disproporci mezi Čechami a Moravou - zákonná ochrana památek totiž podle vládního nařízení příslušela dvěma Zemským úřadům (se sídly v Praze a Brně) v dosahu jejich působnosti, zatímco celou agendu terénních výzkumů měl ve své gesci jediný centralizovaný Archeologický ústav se sídlem v Praze. ${ }^{19}$

Ze Zemského úřadu v Brně odpověděli Huckemu písemně již na počátku ledna 1942, ovšem nebyli konkrétní. Stroze konstatovali, že své stanovisko sdělili Úřadu říšského protektora a ministerstvu školství a národní osvěty. ${ }^{20}$ Byl to logický krok - Úřad ř́šského protektora byl institucí s rozhodovací pravomocí, ministerstvo školství a národní osvěty bylo zase zřizovatelem Archeologického ústavu. Moravský zemský viceprezident Schwabe však nebyl zcela upřímný. Dopis, jímž se obracel na Úřad říšského protektora, totiž žádné stanovisko neobsahoval. ${ }^{21}$

Huckeho podnět z prosince 1941 i Schwabeho dopis z počátku ledna 1942 do Prahy dorazily v době, kdy právě probíhala reorganizace protektorátní vlády, spojená mj. se změnami v ministerstvu školství a národní osvěty. Organizační jednotka Úřadu ř́íského protektora, $v$ níž působil von Both, se na nich výrazně podílela, a tak se Hucke ani po měsíci nedočkal z Prahy žádné odpovědi. Proto svůj návrh v Úřadu ř́išského protektora urgoval. Jelikož se však mezitím setkal z několika stran s negativními (ovšem pouze ústně sdělenými) ohlasy na svůj návrh, pokusil se klíčovou část své argumentace znovu vysvětlit.
Výhrady, s nimiž byl konfrontován, se totiž týkaly podstaty jeho představy - převzetí kompetencí v oblasti archeologické památkové péče na Moravě na úkor Archeologického ústavu. Proto nyní zdůrazňoval: „Stärkt man also das Landesmuseum, so hilft man damit den deutschen wissenschaftlichen Bestrebungen. Die kurz skizzierten unheilvollen Zustände der Denkmalpflege in Mähren können aber nicht von einer weit ausserhalb des Arbeitsgebietes liegenden Anstalt beseitigt werden, sondern sind allein von hier aus in Ordnung zu bringen. So muss ich mich gegen den Vorwurf, die deutschen Belange zu stören, ernstlich verwehren, und den zuständigen Stellen raten, sich einmal näher mit der Vorgeschichtsforschung im Lande Mähren zu befassen."22

Wolf von Both mu z Prahy tentokráte odpověděl vzápětí, a to s omluvou za zdržení způsobené reorganizačními zmatky. Konstatoval, že se s návrhem neztotožňuje, jakkoliv uznával, že stav archeologické památkové péče na Moravě není ideální. Decentralizace v Huckeho pojetí nebyla evidentně na pořadu dne, avšak zároveň nešlo pominout, že zformulovaný návrh má racionální jádro. Von Both proto dodával: „Nach meiner privaten Überzeugung würde durch die Errichtung einer Zweigstelle Brünn der Anstalt das von Ihnen erstrebte Ziel ebenfalls erreicht werden können.“23 Šlo sice pouze o jeho osobní názor, avšak přesto bylo zřejmé, že Huckeho představa v Praze podporu nezíská.

Tři dny poté Úřad říšského protektora informoval Franze Krause, jednoho z nejvyšších německých úředníků v ministerstvu školství a národní osvěty (ke Krausovi srov. Mohn 2018, 146-147, pozn. 275), o neutěšené situaci v archeologické památkové péči na Moravě a inicioval schůzku, která se jí měla zabývat. Na stole byl ostatně konkrétní návrh, avšak nikoliv od Huckeho von Both se totiž přidržel myšlenky o vytvoření brněnské odbočky Archeologického ústavu a pokusil se vnést do svého řešení principiální logiku. Argumentoval analogií s Památkovým úřadem: „Die nächstliegende Lösung wäre die Errichtung einer Zweigstelle Brünn der Anstalt für Vor- und Frühgeschichte unter der Leitung von Dr. Hucke, entsprechend der Zweigstelle Brünn des Prager Denkmalamtes. “24 Bylo to obdobně racionální východisko jako představa zformulovaná Huckem. Do léta 1941 totiž existovaly dva samostatné Památkové úřrady - pro Čechy (se sídlem v Praze) a pro Moravu (se sídlem v Brně). Dne 8. srpna 1941 však byly sloučeny v jediný Památkový úřad v Praze (Denkmalamt in Prag). Z brněnského Památkového úřadu, $\mathrm{v}$ jehož čele stál od jara 1941 Karl Kühn, se stala pouhá odbočka, detašované (autonomní) pracoviště (oficiální název zněl Památkový úřad, odbočka v Brně, resp. Denkmalamt, Zweigstelle Brünn). ${ }^{25}$ Stejný organizační model měl být uplatněn u Archeologického ústavu.

Události následujících (téměř) pěti měsíců (prozatím?) není možné dokumentovat archivními prameny, jakkoliv je jisté, že musela probíhat řada jednání a o celé záležitosti se musela vést také úřední korespondence. Je ovšem jisté, že Hucke svůj původní návrh v průběhu těchto měsíců modifikoval a ve svých úvahách dospěl od pouhého převzetí kompetencí existujícím prehistorickým oddělením Moravského zemského muzea k ideji vytvoření samostatné instituce, jež by se věnovala výhradně archeologické památkové péči a záchranným výzkumům. Relevantními účastníky těchto debat byli nepochybně Karl Hucke, Wolf von Both, Karl Schwabe, Franz Kraus, zřejmě také Camilla 
Streitová z titulu své funkce německé zástupkyně ředitele Archeologického ústavu Jaroslava Böhma ${ }^{26}$ a snad rovněž Lothar Zotz. Do diskuse se však zapojilo také Ahnenerbe, nepochybně z Huckeho podnětu a na jeho podporu. Ahnenerbe mělo ostatně na Moravě své vlastní zájmy, jež se koncentrovaly především na výzkum tamějších jeskyní a paleolitických nalezišté. Dne 13. června 1942 se jednatel Ahnenerbe Wolfram Sievers obracel na moravského zemského viceprezidenta Karla Schwabeho: „Wenn wir heute den Tschechen endgültig das Wasser abgraben wollen, müssen wir versuchen, sie mit ihren eigenen Mitteln zu schlagen und aus Mähren und Brünn nun unsererseits ein Zentrum deutscher Forschung zu machen trachten. (...) Um aber diesen Aufgaben gerecht zu werden, ist es zweckmäß, ja notwendig, der mährischen Bodendenkmalpflege eine möglichst weitgehende Selbständigkeit zuzuweisen und sie von der in wissenschaftlicher und denkmalpflegerischer Hinsicht hinderlichen Zentralisierung von Prag zu lösen; denn praktisch wird Prag gar nicht in der Lage sein, eine wirklich geordnete Denkmalpflege in Mähren durchzuführen." Za jediné vhodné

Dadurch, dass in dieser Veise der landschaftlichen und ve rwaltungsmässigen Gliederung der Provinz Rechnung. getragen wira, entfallen ohne Zwang die mit einer Zentralisation verbundenen, auf die Dauer unüberwindlichen Schwierigkeiten. Aehnliche Lö sungen strebt man in andern Provinzen an, bzw. hat sie schon gefunden.

Tendet man die von der deutsahen Vorgeschichtsforschung auf der Gebiet der Denkmalpilege in Jahrzehnten erworbenen \#rfahrungen und erprobten Methoden an, so ergibt sich als einzig mögliche Folgerung aus den eingangs angefuhrten verwickelten und die Bodenforschung lediglich belastenden Unständen die Forde mung nach einer vollkommenen Selbständigkeit der vorgeschiohtlichen Denkmal pelege in Mähren. Nur auf soloher Grundlage wird es möglich sein, die Bodenforschung im Lande, die noch grösstenteils von tschechischem Ge1st erfullt ist, in deutsche Bahnen zu leiten. So, wie bereits der gesetzliche Schutz der Bodendenkmäler nach der namhaft femachten Regierungsverordnung der mährischen Landesbehörde untersteht, muss auch seine Durchrührung ein Bestandteil der kulturellen Aufgaben des Landes Mähren sein.

Die mährische Landesbehörde besitz in ihrem Landesmus eum das wichtigste Instrument der landschaftilchen Kulturpelege für ihren Bereich. Das Landesmuseum fuhlt sich voll verantwortlich für die Belange der vorgeschichtlichen Denkmalpelege in iähren und beansprucht deshalb als antliche Sinrichtung der Landesbehorde, diese Verantwortung in vollem Unfange zu tragen. Deshalb bitte ich den Herrn Reichsprotektor in Böhmen und Mähren darum, diesen Fragenkomplex in seiner Gesarntheit zu prufen, die Abtrennung der vorgeschichtlichen Denkmalpelege in Mähren von der Anstalt für Vor- und Frihge schichte in Prag vorzunehnen und diese Aufgabe der Abteilung Urgeschichte am Mährischen Landesmuseum in Brünn zu ubiertragen

Obr. 3. Klíčová část Huckeho rozkladu o archeologické památkové péči na Moravě, v níž navrhl převedení kompetencí z Archeologického ústavu na prehistorické oddělení Moravského zemského muzea. NA, fond Úřad říšského protektora v Čechách a na Moravě, sign. I-10 V-4-1, karton 536.

Fig. 3. The key part of Hucke's analysis of archaeological heritage protection in Moravia, in which he suggested to transfer the competences of the Institute of Archaeology to the Department of Prehistory of the Moravian Museum. NA collection Reichsprotektor Office in Moravia and Bohemia, sign. I-10 V-4-1, box 536. 
řešení považoval zcela ve shodě s Huckem „die Denkmalpflege in Mähren in einem selbständigen Institut zusammenzufassen." A dodával: „Nach der in Deutschland gemachten Erfahrungen wird eine gewisse Dezentralisierung auf dem Gebiet der Bodendenkmalpflege, die sich ja von vornherein aus der landschaftlichen Gebundenheit ergibt, immer zu besseren Erfolgen führen. Ich wäre Ihnen deshalb sehr dankbar, wenn Sie sich in diesem Sinne für die Verselbständigung der Bodendenkmalpflege in Mähren einsetzen würden“ “. ${ }^{27}$

Sievers chtěl zřejmě podnítit Schwabeho k odporu proti řešení, které se rýsovalo. Avšak lepšími kartami hrál Wolf von Both. Dne 16. června 1942 se v Brně odehrál rozhovor mezi ním a Schwabem, při němž zřejmě došlo k definitivní dohodě o konstituování brněnské odbočky v rámci Archeologického ústavu. Schwabe svůj souhlas udělil s jedinou podmínkou - chtěl si zachovat dohled nad písemnou komunikací mezi brněnskou odbočkou a pražským ústředím Archeologického ústavu. ${ }^{28}$

Hucke se ještě pokusil běh událostí zvrátit a 18. června 1942 se obrátil na von Botha. Jakkoliv se již smíril s tím, že jeho modifikovaná představa o samostatné instituci archeologické památkové péče pro Moravu nebude realizována, úporně se snažil lobbovat za ni alespoň ve výhledu do budoucna. Mimo jiné uváděl: „Was mich an dem Plan einer selbständigen Stelle für Denkmalpflege in Mähren so zäh festhalten lässt, ist die Erkenntnis, dass wir selbst bei der Errichtung einer Nebenstelle in absehbarer Zeit doch den Weg zu einem selbständigen Amt unter dem Zwang der Notwendigkeit werden finden müssen. “ A poněkud expresivně podotýkal: „Und deshalb möchte ich es auf jeden Fall, soweit es in meinen Kräften steht, verhindern, dass wir in eine Sackgasse hineingeraten." Ke svému dopisu přikládal opis Sieversova dopisu Schwabemu z 13. června 1942, ale marně. ${ }^{29}$ Von Both zanedlouho Huckemu zdvořile, avšak rezolutně odpovídal: „Ich bin persönlich ganz Ihrer Ansicht, daß im Laufe der Entwicklung ein selbständiges Amt für Bodendenkmalpflege in Brünn aus der Außenstelle herauswachsen wird. Zu dem jetzigen Zeitpunkte kann aber nur eine Außenstelle in Betracht kommen, da es unbedingt notwendig ist, daß die gesamte vorgeschichtliche Arbeit im Protektorat nach einheitlichen Gesichtspunkten durchgeführt wird.“30

Ve stejný den psal von Both interně (ovšem oficiálně) také Karlu Hermannu Frankovi a žádal ho o rozhodnutí. Sice se zmínil o Huckeho představě, avšak jednoznačně upřednostňoval konstituování brněnské odbočky v rámci Archeologického ústavu. Upozorňoval: „Da das Gebiet des Protektorats zu ausgedehnt ist, um von Prag aus das besonders fundreiche Mähren ausreichend zu betreuen, ist von dem Schulministerium auf Wunsch unseres Amtes die Gründung einer Außenstelle Brünn der Anstalt für Vor- und Frühgeschichte in Prag vorgesehen. - Ebenso wie das Denkmalamt in Prag eine Außenstelle in Brünn besitzt. "Uváděl, že s tímto postojem se ztotožnil mj. také moravský zemský viceprezident Schwabe, jakkoliv s výhradou, a odkazoval na jednání s ním 16. června 1942 v Brně. K dopisu přiložil Sieversův dopis Schwabemu z 13. června 1942 a Huckeho dopis z 18. června 1942. ${ }^{31}$

V Úřadu ř́išského protektora padlo definitivní rozuzlení teprve za několik týdnů - před Frankem se totiž k návrhu museli vyjádřit dva přímí von Bothovi nadřízení. ${ }^{32}$ Dne 16. července 1942 se von Both obracel na Huckeho a informoval ho o Frankově konečném verdiktu: „In Brünn wird eine Aussenstelle der Anstalt für Vor- und Frühgeschichte aufgebaut. Von der Errichtung eines selbständigen Amtes für Bodendenkmalpflege in Mähren ist vorläufig abzusehen. " Dodával, že o rozhodnutí bude informován moravský zemský viceprezident Schwabe, a s reminiscencí na Huckeho více než měsíc starou poznámku podotýkal: „Ich glaube nicht, dass wir damit in die von Ihnen befürchtete Sackgasse hineingeraten, sondern dass nur auf diesem Wege eine Voraussetzung für den späteren Aufbau eines selbständigen Amtes in Brünn geschaffen werden kann. “"33
Moravský zemský viceprezident Schwabe byl uvědomen teprve šest dnů poté. Dne 22. července 1942 se na něj obrátil sám Karl Hermann Frank s informací o svém rozhodnutí a žádal ho o souhlas s pověřením Karla Huckeho vedením odbočky. Hucke byl totiž jako ředitel Moravského zemského muzea oficiálně zemským zaměstnancem, a Schwabeho svolení bylo tudíž nezbytné, jakkoliv představovalo spíše jen úřední formalitu. ${ }^{34}$

Konstitutivní akt, jímž byla odbočka v Brně zřízena, byl proveden výnosem ministerstva školství z 29. července 1942. Do jejího čela byl postaven Karl Hucke (srov. např. Anonymus 1942a; 1942b). ${ }^{35}$ Von Bothovo řešení z ledna 1942, s nímž přišel v reakci na Huckeho původní návrh, slavilo vítězství.

\subsection{Organizační potíže a spory}

Brněnská odbočka Archeologického ústavu byla sice založena, avšak zprvu šlo patrně o pomyslnou prázdnou schránku, pouhý obal bez obsahu. Nebyly totiž zajištěny rozpočtové prostředky na provoz a zpočátku ani nebylo jasné, jak bude řízena a organizována. Von Both sice již v červenci 1942 Huckemu avizoval, že bude nutné co nejdříve dohodnout prŕíslušné detaily („Sie werden aufdem Wege über den Landesvizepräsidenten gebeten werden, zu einer Besprechung der Einzelheiten über die Aussenstelle hierher zu kommen. Da ich ab 15. August für 14 Tage nicht in Prag sein werde, liegt mir daran, dass wir uns Anfang August hier sprechen können.“), ${ }^{36}$ avšak $\mathrm{k}$ diskusi nakonec došlo zřejmě teprve 8. ř́jna 1942 během zasedání Badatelské rady pro pravěk, koordinačního tělesa protektorátní archeologie zřízeného při Archeologickém ústavu (k Huckeho aktivní účasti na zasedání Badatelské rady pro pravěk ve dnech 8.-9. ř́jna 1942 viz Zotz 1942, 136, 152, 153; Hlava 2018, 18, 19, 27; Hucke mj. v první den proslovil přednášku Neue Funde aus Mähren, v níž prezentoval výsledky výzkumů pohřebišt v Brně-Maloměřicích a Boleradicích). Von Both tehdy Huckemu doporučil, aby z hlediska administrativní organizace využil jako vzor postupy uplatňované v brněnské odbočce Památkového úřadu. ${ }^{37}$ Hucke se proto vzápětí obrátil na jejího vedoucího Karla Kühna ${ }^{38}$ a zřejmě až poté brněnská odbočka Archeologického ústavu zahájila skutečnou činnost. ${ }^{39}$ Teprve 20. ř́jjna 1942 totiž Hucke žádal ministerstvo školství o první dotaci - šlo o 27000 korun, z nichž 20000 korun mělo být určeno na terénní výzkumy. ${ }^{40} \mathrm{~K}$ dispozici však byly teprve 16. listopadu $1942 .{ }^{41}$

Terénní aktivity pod záštitou brněnské odbočky Archeologického ústavu zprvu zajištovali zaměstnanci prehistorického oddělení Moravského zemského muzea, resp. muzejního Ústavu Anthropos, jehož vedoucím se stal 15. září 1942 Hermann Schwabedissen, další z říšskoněmeckých prehistoriků v protektorátní archeologii. Stejně jako Hucke byl také Schwabedissen dočasně uvolněn z wehrmachtu, utrpěl totiž zranění na východní frontě (Hlava 2020b, 327, pozn. 96). Měl rovněž úzké vazby k Ahnenerbe, jež se ostatně podílelo na jeho příchodu do Brna. Patrně první terénní akcí, jež byla proplacena z prostř̌edků určených na činnost odbočky, byl terénní průzkum Josefa Skutila v Brankovicích, který proběhl 1. října 1942. ${ }^{42}$ Avšak první skutečný terénní výzkum se odehrál na paleolitické stanici v Ondraticích, a to (s přestávkami) od 15. ř́ína do 21. listopadu 1942, pod vedením Hermanna Schwabedissena a technika Emanuela Danii. ${ }^{43}$ Hlavní tíha terénních prací odbočky ovšem zřejmě od počátku spočívala na Josefu Poulíkovi. Jeho první terénní aktivity (v Dambořicích a okolí), jež byly financované brněnskou odbočkou, se uskutečnily ve dnech 21.-24. ř́jna 1942 (výzkumu v Dambořicích 24. ř́jna 1942 se kromě Poulíka zúčastnil také Karl Hucke). Zjevně nepostradatelný Poulík se stal právě proto 23. prosince 1942 prvním stálým českým zaměstnancem odbočky. ${ }^{44}$ Záhy jej následovali Miroslav Knapil (od 1. ledna 1943) 


\section{Wacum gibt es ein Gesetz aum Schutz der Badenaltertïmer?}

Am 12. VI. 1941 hat die Protektoratsregierung eine Verordnung zum Schutz der Bodénaltertümer erlassen, deren Inhalt sich in folgende Sätze zusammenfassen läßt:

1. Bodenaltertümer, d. h. Werkzeuge, Waffen, Schmuck und andere Gegenstände aus der Vor- und Frühgeschichte, aber auch Plätze, an denen Bodenaltertümer gefunden werden (Grabhügel, Flachgräberfelder, Siedlungen und Burgwälle), dürfen weder verändert noch vernichtet werden. Sie stehen unter dem Schutz der Landesbehörde.

2. Für den Bereich des Landes Mähren hat das Ministerium für Schulwesen das Ámt für Vorgeschichte in Brünn zum amtlichen Berater und behördlichen Sachverständigen in den Angelegenheiten des Schutzes der Bodenaltertümer bei der Landesbehörde in Brünn ernannt.

3. Wird bei Erdarbeiten oder anderen Gelegenheiten ein Fund entdeckt, so hat der Finder, der Leiter der Arbeiten oder der Grundbesitzer innerhalb von 48 Stunden entweder dem Amt für Vorgeschichte in Brünn, dem Gemeindevorsteher oder der Gendarmeriestation Meldung zu erstatten.

4. Fund und Fundplatz sind bis zum Eintreffen des Vertreters des Amtes für Vorgeschichte, längstens aber 4 Tage, unverändert zu lassen, soweit das ohne bedeutende Kosten oder Nachteile möglich ist. Bewegliche Altertümer sind Eigentum des Protektorates Böhmen und Mähren.

5. Entsteht für den Finder oder den Grundbesitzer infolge der Durchführung der Verordnung ein Schaden, so ist die Möglichkeit eines Ersatzes gegeben. Übertretungen der Verordnung werden in schweren Fällen mit einer Geldbuße bis zu $300.000 \mathrm{~K}$ oder mit Arrest bis zu 6 Monaten bestraft. Warum sind nun diese Bestimmungen getroffen worden?

Bodenaltertümer sind Zeugen aus der Vorzeit unserer Heimat. Sie geben uns Kunde vom Leben und Schicksal unserer Vorfahren, denn in so früher Zeit sind keine Nachrichten aufgezeichnet worden. $\mathrm{Da}$ die Erklärung und Bearbeitung der Funde aber eine eingehende Vorbildung erfordert, ist nur ein wissenschaftliches Amt zu ihrer Betreuung berufen.

Wer daher mutwillig Bodenfunde zerstört oder absichtlich die vorgeschriebene Meldung unterläßt, versündigt sich nicht nur an seiner Heimat, sondern fügt auch der Wissenschaft empfindlichen Schaden zu. Besitzer und Entdecker von Bodenaltertümern beachten also folgende Regel:

1. Jeder Fund ist solort zu melden!

2. Der Fundplatz und die Fundumstände sind sehriftlich gencu festzulegen.

3. Beim Fuftreten von Funden dart der Fundplatz nicht berihrt werden.

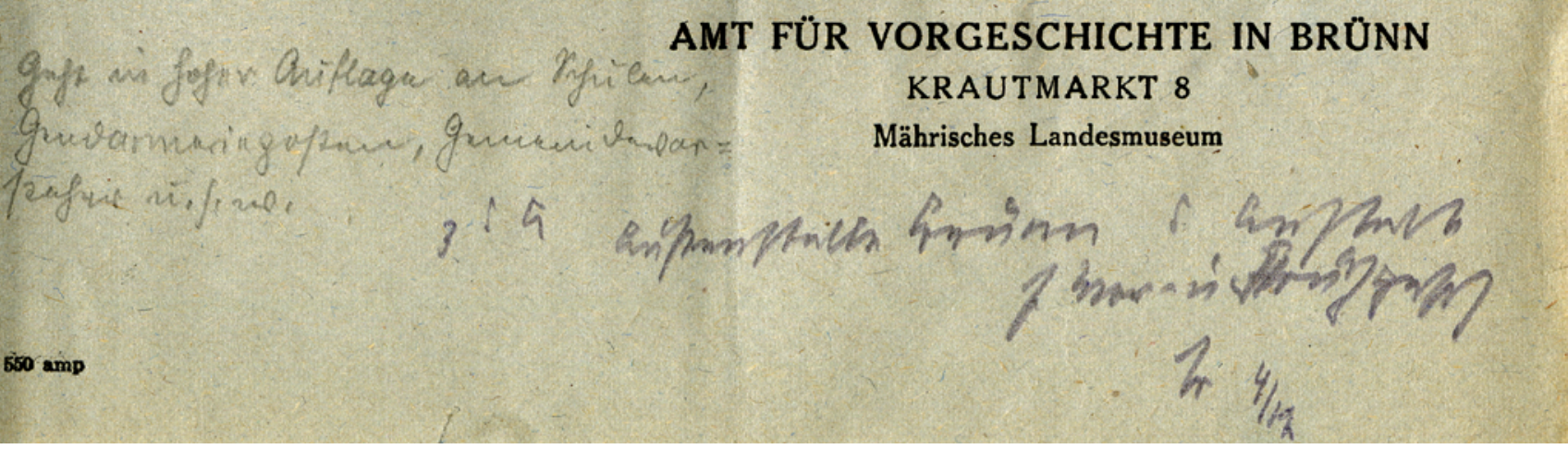


a Jaroslav Hochmann (od 1. července 1943), v odbočce př́ležitostně vypomáhal Bedřich Vyskočil a na počátku roku 1943 s ní krátce spojila své osudy Květuše Procházková. ${ }^{45}$

Poulíkovo úřední přemístění z prehistorického oddělení Moravského zemského muzea do brněnské odbočky Archeologického ústavu před Vánocemi 1942 proběhlo v době, kdy její titulární vedoucí Karl Hucke již nebyl v Brně. Přes usilovnou snahu moravského zemského viceprezidenta Karla Schwabeho, Wolfa von Botha z Úřadu říšského protektora či Wolframa Sieverse z Ahnenerbe se totiž na podzim 1942 nepodařilo prodloužit jeho uvolnění z armády, a tak se Hucke musel 7. prosince 1942 vrátit do wehrmachtu. ${ }^{46}$ Zastupujícím ředitelem Moravského zemského muzea byl neprodleně jmenován Edmund Küttler, složitější situace však nastala v brněnské odbočce Archeologického ústavu. Nový (ovšem zastupující) ředitel muzea sice pověřil jejím dočasným řízením již 9. prosince 1942 Josefa Poulíka, ${ }^{47}$ avšak šlo pouze o provizorní řešení, jež v sobě navíc skrývalo prvek absurdity - odbočka totiž nebyla součástí Moravského zemského muzea (tř̌ebaže sídlila v jeho prostorách), a Küttlerův zásah do jejího chodu byl tudíž právně problematický. Teprve 16. prosince 1942 se v Praze odehrála schůzka mezi Wolfem von Bothem, Camillou Streitovou a Hermannem Schwabedissenem, na níž došlo $\mathrm{k}$ dohodě o vyřešení situace po Huckeho odchodu do wehrmachtu. Vedením brněnské odbočky Archeologického ústavu byl pověřen Hermann Schwabedissen, ovšem pouze jako zastupující vedoucí (stellvertretender Leiter); zároveň zůstal vedoucím muzejního Ústavu Anthropos. ${ }^{48}$ Huckeho ředitelování brněnské odbočce (ale také muzeu) tudíž oficiálně nadále trvalo.

Při pohledu nazpět je zřejmé, že Huckeho odchod z Brna na přechodnou dobu utlumil počínající konflikty mezi ním a Camillou Streitovou. Na vině byl ovšem jednoznačně sám Hucke, který se nesmíril s podř́izenou rolí brněnské odbočky ve vztahu k pražskému ústředí Archeologického ústavu a vydal se na cestu tichého vzdoru. Třebaže podřízení brněnské odbočky pražské centrále Archeologického ústavu a její oficiální název byly jednoznačně stanoveny, Hucke pro toto pracoviště začal používat název Amt für Vorgeschichte in Brünn. Tímto názvem dokonce opatřil oficiální úřední tiskopisy (obr. 4). Reakce na sebe pochopitelně nenechala dlouho čekat. V únoru 1943 zaslala Camilla Streitová jednu z obálek s předtištěným Amt für Vorgeschichte in Brünn př́mo Wolfu von Bothovi, jehož na tuto záležitost předem telefonicky upozornila. ${ }^{49}$ Von Both nelenil a záhy sděloval do Brna: „Ich ersuche diese Bezeichnung unverzüglich ausser Gebrauch zu stellen und in dem amtlichen sowie überhaupt im schriftlichen Verkehr ausschliesslich nur die richtige Bezeichnung, Anstalt für Vor- und Frühgeschichte - Aussenstelle Brünn' zu benützen. " ${ }^{50}$ Von Bothovi však z Brna odpověděl nikoliv Schwabedissen, ale sám Hucke, který zde zrovna trávil dovolenou. Sděloval, že „,iie Aussenstelle im Einvernehmen mit Herrn Ob. Reg. Rat Dr. von Both nach dem Vorbild des Denkmalamtes in Brünn ausgebaut wurde und gleich dem Denkmalamte in Brünn die kurze Bezeichnung, Amt für Vorgeschichte in Brünn' erhielt. Dieser Name wurde von mir nach Aussprache mit Herrn Prof. Dr. Kühn gewählt und dem Ministerium bekanntgegeben. Seit Oktober vergangenen Jahres verlief alle
Arbeit des Amtes unter diesem Namen, auch werden Merkblätter, Briefköpfe, Briefumschläge und Stampiglien auf lange Sicht mit dieser Bezeichnung herausgegeben." A považoval tím celou záležitost za uzavřenou. ${ }^{51}$ Avšak von Bothovi došla trpělivost a v rozporu s obvyklou úřední zdrženlivostí byl velmi důrazný. Opakoval, že název používaný Huckem je nesprávný, a dodával: „Ich habe von vornherein Wert darauf gelegt, auch in dem Namen der Aussenstelle ihre organisatorische Verbindung mit der Prager Anstalt zum Ausdruck zu bringen. Ich kann daher dem dortigen Gesuche um die weitere Belassung dieser unrichtigen Bezeichnung nicht stattgeben." "52 Ani to ale nebylo poslední slovo. Schwabedissen totiž Huckeho o von Bothově neoblomném postoji informoval při osobním setkání na počátku léta 1943 v Lipsku, kde Hucke sloužil ve vojenském lazaretu. Hucke poté von Bothovi znovu připomínal, že brněnská odbočka Archeologického ústavu měla být vybudována podle vzoru brněnské odbočky Památkového úřadu: „Nach Aussprache mit Herrn Professor Kühn habe ich das getan und, in einer Erörterung mit Herrn Professor Kühn, für die Außenstelle den Namen ,Amt f. Vorgeschichte in Brünn' festgelegt. Ist das von Herrn Professor Kühn verwaltete Amt doch gleichfalls eine Außenstelle des Prager Instituts, ohne daß diese Bindung in der Namensgebung, Denkmalamt in Brünn' (vergl. den Briefkopf) zum Ausdruck kommt." To ale nebylo vše. Hucke totiž využil př́ležitosti a znovu zdůraznil svůj postoj k současnému stavu. Brněnská odbočka v rámci Archeologického ústavu byla pro něho ve stávající podobě zjevně nemilovaným dítětem: „Zwar bin ich mir nach wie vor darüber im Klaren, daß die gegenwärtige Lösung aus mancherlei Gründen nicht zu umgehen war, ohne daß ich allerdings Herrn Professor Zotz als dem amtlichen Berater bei der Ausarbeitung der Reg. Verordnung den Vorwurf einer mangelhaften Einsicht in die Verhältnisse ersparen kann, ich habe auch auf Anraten von Herrn Standartenführer Sievers, dessen klare Ansicht über diesen Punkt ja schriftlich festliegt, meine Bedenken schweren Herzens zurückgestellt; es ist aber immer wieder darauf hinzuweisen, daß der augenblickliche Zustand nur ein vorübergehender sein kann. “53

Eskapáda s oficiálním názvem brněnské odbočky ovšem nebyla jediným Huckeho sporem s pražským ústředím Archeologického ústavu. Mezi Huckem a Streitovou prý došlo ještě v roce $1942 \mathrm{k}$ dohodě, že od každé nové nálezové zprávy bude zhotovena kopie, jež bude zaslána do pražského ústředí, kde bude uložena do tamějšího archivu. Bylo stanoveno, že během zimy budou nálezové zprávy zasílány měsíčně, v létě pak jednou za dva měsíce. O dohodě byl údajně informován také Josef Poulík. Avšak realita byla jiná a Streitová na to v polovině roku 1943 upozorňovala von Botha: „Auf unsere Urgenzen erhalten wir jedoch nunmehr nur ganz übersichtliche Tätigkeitsberichte, die für die Weiterführung der Archivakten nicht verwendbar sind." $\mathrm{Hu}-$ ckeho postoj byl totiž jednoznačný a souvisel s jeho snahou o samostatnost: „Herr Dr. Hucke steht auf dem Standpunkte, dass die Aussenstelle ein selbstständiges Institut ist, dass daher die jetzige Art der Berichterstattung vollauf genüge." Streitová proto žádala von Botha o úřední zásah. ${ }^{54}$ Von Both teprve za více než dva měsíce přikazoval do Brna Schwabedissenovi, aby respektoval původní dohodu mezi Huckem a Streitovou. ${ }^{55}$ Schwabedissen na konci

Obr. 4. Tištěný leták s informacemi o vládním nařízení o archeologických památkách. Pozoruhodné je použití názvu Amt für Vorgeschichte in Brünn v souvislosti s Moravským zemským muzeem - viz vpravo dole. NA, fond Úřad říšského protektora v Čechách a na Moravě, sign. I-10 V-5-1, karton 538.

Fig. 4. A printed leaflet with information on the Government decree on archaeological heritage. The title Amt für Vorgeschichte in Brünn used in association with the Moravian Museum - bottom right - is noteworthy. NA, collection Reichsprotektor Office in Bohemia and Moravia, sign. I-10 V-5-1, box 538. 
ř́jna 1943 odpovídal: „Da nach den Angaben von Herrn Direktor Hucke die Frage der Berichterstattung seinerzeit nicht in dem angegebenen Sinne geregelt worden sei, müsste ich diesem die Beantwortung des bez. Schreibens überlassen." Dodával, že Hucke již ministerstvu poslal svoji odpověd'. ${ }^{56}$ Jenže ta nedorazila ani během následujícího měsíce, a tak von Both v první prosincový den roku 1943 znovu žádal Schwabedissena o respektování svého nařízení ohledně nálezových zpráv. ${ }^{57}$ Avizovaný Huckeho dopis přišel do Prahy teprve těsně před polovinou prosince 1943. Hucke v něm popřel dohodu se Streitovou o zhotovování kopií nálezových zpráv, nebot podle něj mělo jít pouze o souhrnné informování o terénních akcích. Neopomenul uvést, že vypracování kopií pro pražské ústředí považuje za zbytečnost, která navíc brněnskou odbočku výrazně zatěžuje. ${ }^{58}$ Von Both však stál na straně Streitové a byl opět rezolutní: „Ich bin damit einverstanden, dass die seit Begründung der Aussenstelle entstandenen älteren Fundberichte von der Anstalt in Prag abgeschrieben werden, falls diese Arbeit jetzt in Brünn nicht geleistet werden kann. ${ }^{\text {} 59}$

Někdy na přelomu jara a léta 1943 se Hucke pokusil o další manévr na cestě k osamostatnění brněnské odbočky. Vytasil se totiž s návrhem jejího organizačního statutu, který zaslal Streitové. Pokud by byl přijat, získala by brněnská odbočka v rámci Archeologického ústavu naprostou autonomii, bez možnosti organizačních (či jakýchkoliv jiných) zásahů ze strany pražského ústředí. V Huckeho představě měla být podřízena přímo ministerstvu školství, jakkoliv formálně měla být součástí pražského Archeologického ústavu. ${ }^{60}$ Streitová to vcelku pochopitelně odmítla: „Eine Abtrennung Mährens von Böhmen bzw. die Schaffung eines eigenen Landesamtes in Brünn, die Sie mit diesem Statutentwurfneuerlich anstreben, könnte bei der momentanen politischen Situation nur schädlich sein. Glauben Sie, nur für Sie wäre es angenehmer, wenn Brünn ein eigenes Landesamt wäre. O nein, auch für mich! Aber unsere persönlichen Wünsche in dieser Richtung sind völlig nebensächlich. Für mich jedenfalls ist einzig und allein massgebend, dass bezüglich des Verhältnisses zwischen Brünn und Prag eine ganz klare Entscheidung des Herrn Staatssekretärs vorliegt, die abzuändern derzeit nicht der geringste Grund besteht." A rezolutně dodávala: „Dies meine grundsätzliche Einstellung.“61

Karl Hucke však neměl spory pouze s pražskou centrálou Archeologického ústavu, ale také s Hermannem Schwabedissenem. Jablkem sváru se zprvu stalo postavení Ústavu Anthropos. Schwabedissenovým cílem totiž bylo jeho osamostatnění od Moravského zemského muzea. Narazil ovšem na Huckeho nesouhlas, a tak se snažil získat podporu u Wolframa Sieverse $\mathrm{v}$ Ahnenerbe. Ten mu však v červnu 1943 doporučil probrat celou záležitost př́mo s Huckem (Oliva, Kostrhun 2019, 120). Na počátku léta 1943 došlo skutečně k jejich setkánív Lipsku, kde tehdy Hucke sloužil ve vojenském lazaretu. ${ }^{62} \mathrm{~K}$ dohodě nedošlo, avšak nedůvěra mezi Huckem a Schwabedissenem tím byla zaseta. Hucke se začal obávat, že bude odstraněn z muzea i brněnské odbočky. Právě ve světle těchto obav je nutné nahlížet na Huckeho nečekaný krok z počátku února 1944, kdy z titulu funkce vedoucího odbočky pověril během svého krátkého pobytu v Brně Josefa Poulíka př́stupem k bankovnímu účtu po dobu své nepřítomnosti a zároveň tohoto práva zbavil Hermanna Schwabedissena. ${ }^{63}$ Wolf von Both poté Huckemu zcela bez obalu sděloval: „Ich muss Ihnen ganz offen sagen, dass ich nicht begreife, wie Sie zu diesem Schritt kommen konnten. Es muss Ihnen doch klar sein, dass sie nicht befugt sind, ohne Wissen des Ministeriums Ihren Vertreter einfach auszuschalten, wie Sie es durch Ihr Schreiben an die Brünner Postsparkasse versucht haben. (...) Ausserdem ist es natürlich ganz unmöglich, dass Sie einem deutschen aktiven Beamten die Zeichnungsberechtigung zu Gunsten einer tschechischen Hilfskraft in dieser Form entziehen." To ale nebylo vše. Von Both totiž jakékoliv další Huckeho zásahy do chodu brněnské odbočky Archeologického ústavu podmínil jeho přeložením do Brna či okolí: „Das Schulministerium wird die Vertretung von Dr. Schwabedissen aufheben, sobald Sie nach Brïnn oder in die allernächste Umgebung von Brünn versetzt sind und sobald feststeht, dass Sie die Möglichkeit haben, sich genügend um die Aussenstelle zu kümmern. Zum gegebenen Zeitpunkt wird eine entsprechende Meldung von Ihnen hier erwartet. Wenn es soweit ist, wird in einer Besprechung bei Ministerialrat Dr. Heckel oder bei mir den Prager und Brünner deutschen Vorgeschichtsforschern Gelegenheit gegeben werden, den Weg zu einer fruchtbaren Zusammenarbeit im Rahmen der bestehenden Verhältnisse zu finden, wie sie für die Sache unumgänglich nötig ist. “64 Hucke tím byl vyřazen ze hry a do osudů brněnské odbočky Archeologického ústavu již nezasáhl.

V době, kdy von Both formuloval dopis Huckemu, se však již schylovalo k další změně. Už v červnu 1943 byl Hermann Schwabedissen znovu odveden do wehrmachtu, ale 540. divize, do níž byl zařazen, byla prozatím dislokována v Brně. ${ }^{65}$ Nadále se tudíž mohl věnovat svým povinnostem v Moravském zemském muzeu i v brněnské odbočce Archeologického ústavu. Avšak na konci února 1944 byl odvelen na frontu. Veškeré pokusy zabránit jeho odchodu z moravské metropole byly neúspěšné. Schwabedissenovo působení na Moravě bylo u konce. ${ }^{66}$

Brněnská odbočka se opět ocitla v provizoriu. Již 2. března 1944 sdělovala Camilla Streitová Josefu Poulíkovi, že „bis zu einer Neuregelung durch das Ministerium für Schulwesen die Weisungen für Ihre Arbeit von der Anstalt in Prag durch Herrn Dr. Mähling erhalten. ${ }^{{ }^{67} 7}$ Werneru Mählingovi, který byl od jara 1942 zaměstnán v Archeologickém ústavu jako druhá tamější německá odborná síla, připadl vskutku nevděčný úkol (k Mählingovi blíže Reinhard 2008). O chod brněnské odbočky se ale zřejmě staral především z Prahy, ostatně k avizovanému ministerskému rozhodnutí, jímž by se úředně vyřešila situace po Schwabedissenově odchodu, nikdy nedošlo. Také Mähling však musel v průběhu roku 1944 z Protektorátu Čechy a Morava odejít; na činnost brněnské odbočky poté dohlížela Camilla Streitová.

Když se v létě 1944 schylovalo k uzavření kulturních a vědeckých institucí, Streitová prosazovala ukončení činnosti pražského ústředí Archeologického ústavu i brněnské odbočky (Blažek 2003, 589, 599-601). Nakonec došlo pouze k výraznému omezení činnosti, jež mnohem více postihlo pražskou centrálu. Brněnská odbočka zůstala přes veškerou snahu Camilly Streitové v omezeném provozu až do jara 1945, a to především díky pasivní rezistenci jejích českých zaměstnanců, ovšem za vydatné podpory Karla Kühna, ředitele místní odbočky Památkového úřadu. ${ }^{68} \mathrm{~V}$ květnu 1945 začala nová éra.

\section{Závěr}

Z rekonstrukce sledu událostí, jež vedly v létě 1942 ke vzniku brněnské odbočky Archeologického ústavu, naprosto přesvědčivě vyplývá, že její konstituování bylo kompromisem mezi snahou Karla Huckeho získat kompetence v oblasti archeologické památkové péče pro region, $v$ němž měl aktivně působit, a centralizačními principy, jež zastával Úřad ř́íšského protektora. Huckeho původní představa z prosince 1941 byla od konečného výsledku vskutku výrazně odlišná - podstatou jeho návrhu bylo převzetí pravomocí pro Moravu prehistorickým oddělením Moravského zemského muzea od Archeologického ústavu. Decentralizace tohoto typu ale z pohledu Úřadu říšského protektora nepřicházela v úvahu, a tak bylo zvoleno řešení, které sice Huckemu vycházelo maximálně vstříc, zároveň ale ponechávalo rozhodující pravomoci v pražském ústředí Archeologického ústavu. Z pohledu organizačního modelu šlo vlastně o analogické uspořádání jako v př́ípadě $\mathrm{Pa}-$ mátkového úřadu, u něhož ovšem brněnská odbočka vznikla v roce 1941 přetvořením samostatné instituce, nikoliv zcela od základů. 
Záměr konstituovat brněnskou odbočku Archeologického ústavu paradoxně nevznikl v pražském ústředí instituce, a nevycházel tudíž primárně z jejích interních potřeb. Ostatně po sporech (a zkušenostech) s Innocencem Ladislavem Červinkou z 30. let 20. století ohledně míry jeho autonomie byl Archeologický ústav z hlediska organizačních principů cíleně centralizován. V tomto kontextu proto není překvapivé, že dochované (a doposud identifikované) archivní prameny nezachycují žádný podíl národnostně českých prehistoriků na diskusích o decentralizaci instituce ( $\mathrm{k}$ níž ve svém důsledku vedl vznik brněnské odbočky) či obecněji archeologické památkové péče - do př́slušných debat (a mechanismů rozhodování) patrně vůbec nezasáhl ani Jaroslav Böhm, titulární ředitel Archeologického ústavu. V této souvislosti stojí ovšem také za pozornost, že klíčová jednání a rozhodnutí v červnu a červenci 1942 probíhala zčásti v době stanného práva po atentátu na zastupujícího říšského protektora Reinharda Heydricha.

Ideovým tvůrcem brněnské odbočky Archeologického ústavu byl nepochybně Wolf von Both, od jara 1941 subalterní úředník v Úřadu říšského protektora, do jehož kompetence spadala protektorátní archeologie. Jeho hlavní profesní zájem ovšem patřil knihovnictví - s jistou nadsázkou lze tudíž konstatovat, že dnešní brněnský Archeologický ústav vděčí za svůj vznik především knihovnickému radovi z Berlína (k von Bothovu profesnímu zaměření viz Mohn 2018, 272).

Huckeho úsilí o nezávislé postavení na pražském ústř̌edí Archeologického ústavu rozhodně nelze považovat za projev regionálního patriotismu. Šlo prostě o snahu získat potřebné pravomoci a samostatnost, ovládnout teritorium, v němž působil. Je ostatně charakteristické, že pokusů o autonomní postavení se nevzdal ani po vzniku brněnské odbočky - z jeho pohledu byla míra decentralizace nedostatečná. Konflikty, jež poté Huckeho neústupné jednání opakovaně vyvolávalo, ostatně představují jen další kamínek do mozaiky spletitých vztahů mezi jednotlivými ř́šskoněmeckými prehistoriky působícími v protektorátní archeologii i německými úředními místy. Ty totiž rozhodně neměly ideologické pozadí (srov. velmi výstižně Oliva, Kostrhun 2019, 129-130) a až překvapivě často ústily do osobní averze, vzájemného podezrrívání a nechuti ke spolupráci. Právě proto někteří z řríšskoněmeckých prehistoriků neváhali spolupracovat s národnostně českými prehistoriky za zády svých německých kolegů, třebaže to bylo v zásadním rozporu s principy, které měli respektovat. Ostatně korektní vztah mezi Lotharem Zotzem a Jaroslavem Böhmem od roku 1942 vyústil dokonce v tiché spojenectví proti Camille Streitové (podrobně Hlava 2018, 537-541, 549-552). A do stejného soudku lze nepochybně zařadit také výše zmíněné $\mathrm{Hu}-$ ckeho udělení podpisového práva pro finanční operace Josefu Poulíkovi v únoru 1944, jímž zároveň zbavil tohoto privilegia Hermanna Schwabedissena.

Existenci osobních sporů, jež ( $z$ německého pohledu) neblaze ovlivňovaly německé plány $\mathrm{v}$ protektorátní archeologii, si velmi dobře uvědomoval také Wolf von Both, jak konstatoval v jednom z dopisů Karlu Huckemu: „Es ist tief bedauerlich, dass die deutschen Vorgeschichtsforscher in Böhmen und Mähren im allgemeiner Kampfstellung gegeneinander stehen. “" ${ }^{69}$ Právě z tohoto pohledu je paradoxní, že principy stanovené Úřadem říšského protektora respektovala a prosazovala především Camilla Streitová, jíž Wolf von Both prakticky ve všech sporech dával za pravdu. Z jeho pohledu totiž byla spolehlivá a naprosto loajální. Někteří z jejích soukmenovců však na ni nahlíželi s neskrývaným despektem. Žena v archeologii, a navíc ve vedoucí pozici (Camilla Streitová jako německá zástupkyně ředitele Jaroslava Böhma fakticky ovládala Archeologický ústav), byla totiž tehdy stále bílou vránou. Uved'me alespoň dva dobové komentáře. Karl Hucke v únoru 1944 sděloval Wolfu von Bothovi: „Es ist Ihnen bekannt, daß ich im Sachen der Außenstelle eigene berechtigte Ansichten im Interesse verwaltungspolitischer Belange hinterngesetzt und mich einer Fachgenossin ohne besondere wissenschaftliche Erfahrung untergeordnet habe, ohne viel Aufhebens darum zu machen. “70 A Otto Kleemann, který se v roce 1942 ucházel o místo v protektorátní archeologii a Camillu Streitovou zřejmě vủbec osobně neznal, psal Lotharu Zotzovi: „Es wird ja auf die Dauer kaum angängig und auch arbeitsmäßig gar nicht durchführbar sein, daß die böhmische Denkmalpflege, für die man Frau Dr. Streit eingesetzt hat, von einer Frau organisiert und geleitet wird." (viz též Hlava 2020b, 328).

Vznik brněnské odbočky Archeologického ústavu v roce 1942 představoval nepochybně racionální a kvalitativně zdařilý akt, obdobně jako např. vládní nařízení o archeologických památkách z př̀edchozího roku. Nikoliv náhodou oba konstitutivní počiny př̀etrvaly turbulentní změny roku 1945.

\section{Poznámky}

1 Srov. jednotlivé jmenovací dekrety s nekonsekventními názvy úředních funkcí. J. A. Jíra: dopis ministerstva školství a národní osvěty J. A. Jírovi, 16. ř́jna 1921 (opis); Masarykův ústav a Archiv AV ČR (MÚA AV ČR), fond Státní archeologický ústav, karton 3, inventární číslo (inv. č.) 27 (osobní spis J. A. Jíry). I. L. Červinka: dopis ministerstva školství a národní osvěty I. L. Červinkovi, 8. července 1920; archiv Archeologického ústavu Moravského zemského muzea, nezpracovaná pozůstalost I. L. Červinky; srov. též opis dekretu uložený v MÚA AV ČR, fond Státní archeologický ústav, karton 2, inv. č. 27 (osobní spis I. L. Červinky). J. Eisner: dopis ministerstva školství a národní osvěty J. Eisnerovi, 5. července 1920; MÚA AV ČR, fond Státní archeologický ústav, karton 2, inv. č. 27 (osobní spis J. Eisnera).

2 Dopis L. Niederla Státnímu archeologickému ústavu, 18. března 1933 (opis); MÚA AV ČR, fond Státní archeologický ústav, karton 2, inv. č. 27 (osobní spis I. L. Červinky).

3 Př́pis J. Böhma ze 4. (?) srpna 1931 na dopise I. L. Červinky ředitelství Státního archeologického ústavu ze 4. července 1931; MÚA AV ČR, fond Státní archeologický ústav, karton 2, inv. č. 27 (osobní spis I. L. Červinky).

4 Dopis L. Niederla Státnímu archeologickému ústavu, 18. března 1933 (opis); MÚA AV ČR, fond Státní archeologický ústav, karton 2, inv. č. 27 (osobní spis I. L. Červinky).

5 Dopis J. Böhma ministerstvu školství a národní osvěty, 3. prosince 1938 (koncept); MÚA AV ČR, fond Státní archeologický ústav, karton 5, inv. č. 39. Volontérské místo po Rudolfu Turkovi získal v květnu 1937 Jan Rataj (srov. též Rataj et al. 2003, 142-143 s odlišným datem 1. dubna 1937).

6 Dopis Kanceláře prezidenta republiky Nejvyššímu účetnímu kontrolnímu úřadu, 10. března 1938 (opis); Národní archiv (NA), fond Ministerstvo školství, karton 3193, složka Pražský hrad, spis číslo jednací (čj.) 28325/1939. Viz též dopis Nejvyššího účetního kontrolního úřadu ministerstvu školství a národní osvěty, 25. června 1938; tamtéž.

7 Dopis ministerstva školství a národní osvěty I. Borkovskému, 22. dubna 1939 (opis); MÚA AV ČR, fond Státní archeologický ústav, karton 2, inv. č. 27 (osobní spis I. Borkovského). Dopis ministerstva školství a národní osvěty Nejvyššímu účetnímu kontrolnímu úřadu, 13. června 1939 (koncept); NA, fond Ministerstvo školství, karton 3193, složka Pražský hrad, spis čj. 28325/1939. Viz též dopis Kanceláře prezidenta republiky Státnímu archeologickému ústavu, 6. prosince 1938 (opis); tamtéž. 
8 Dopis ministerstva školství a národní osvěty V. Menclovi, 17. června 1939; MÚA AV ČR, fond Státní archeologický ústav, karton 3, inv. č. 27 (osobní spis V. Mencla).

9 Dopis J. Böhma Státnímu památkovému úřadu pro Čechy (s opisem dopisu J. Böhma ministerstvu školství a národní osvěty ze 14. dubna 1939), 14. dubna 1939 (opis); NA, fond Státní památková správa, karton 646, spis čj. 1656/1939.

10 Posudek: dopis H. Böhmeho K. von Burgsdorffovi, 22. listopadu 1940; NA, fond Úřad říšského protektora v Čechách a na Moravě, signatura (sign.) 114-197/2, karton 195 (nezpracovaná část). Doplnění posudku: dopis H. Böhmeho K. von Burgsdorffovi, 2. prosince 1940; tamtéž.

11 Lebenslauf und Nachweis der wissenschaftlichen Ausbildung und Tätigkeit (K. Hucke), 25. srpna 1940; NA, fond Úřad ř́šsského protektora v Čechách a na Moravě, sign. 114-197/2, karton 195 (nezpracovaná část).

12 Dopis H. Reinholda K. Huckemu, 29. záŕí 1940 (kopie); NA, fond Úřad říšského protektora v Čechách a na Moravě, sign. 114-197/2, karton 195 (nezpracovaná část). Srov. též dopis H. Reinholda K. Huckemu, 11. listopadu 1940 (kopie); tamtéž.

13 Srov. např. dopis K. Huckeho H. Reinholdovi, 10. května 1941; NA, fond Úřad říšského protektora v Čechách a na Moravě, sign. 114-197/2, karton 195 (nezpracovaná část) („Da ich zu einem Truppenteil gehöre, der sowohl in Griechenland als auch in Jugoslawien eingesetzt wurde, bin ich immer noch im Ausland, z. Zt. im südlichen Pelopones.").

14 Dopis L. Zotze dr. Hanselovi, 6. srpna 1941; NA, fond Úřad říšského protektora v Čechách a na Moravě, sign. 114-197/2, karton 195 (nezpracovaná část). Viz též dopis K. Huckeho W. von Bothovi, 22. srpna 1941; tamtéž („Ich wurde mit Wirkung vom 21. 8. vom Feldheer zum Ersatztruppenteil versetzt, da meine Feldeinheit für Afrika vorgesehen ist, und mein Verbleib sich dort aus gesundheitlichen Gründen nicht durchführen ließ.").

15 Dopis K. Schwabeho řŕšskému protektorovi v Čechách a na Moravě, 7. listopadu 1942; NA, fond Úřad říšského protektora v Čechách a na Moravě, sign. 114-197/2, karton 195 (nezpracovaná část) („Ende August 1941 wurde er aus gesundheitlichen Gründen zum Ersatztruppenteil versetzt und Ende Oktober 1941 Uk-gestellt.“). Viz též dopis K. Huckeho Úřadu ř́šského protektora (W. von Both), 29. ř́jna 1942; tamtéž. Tzv. Uk-Stellung (resp. die Unabkömmlichstellung) pro přechodné uvolnění z armády bylo možné získat, pokud byl žadatel nepostradatelný pro válečné hospodářství, dopravu či správu.

16 Korespondence $\mathrm{k}$ Huckeho uvolnění $\mathrm{z}$ wehrmachtu (včetně následných žádostí o prodloužení) je uložena v NA, fond Úřad ř́šského protektora v Čechách a na Moravě, sign. 114-197/2, karton 195 (nezpracovaná část).

17 Dopis K. Huckeho W. von Bothovi, 14. listopadu 1941; NA, fond Úřad říšského protektora v Čechách a na Moravě, sign. 114-197/2, karton 195 (nezpracovaná část).

18 K datu schůzky viz dopis W. von Botha K. Huckemu, 15. listopadu 1941 (koncept); NA, fond Úřad říšského protektora v Čechách a na Moravě, sign. 114-197/2, karton 195 (nezpracovaná část) („Ich stehe Ihnen am Donnerstag, dem 20. 11., um 16,30 Uhr zur Verfügung.").

19 Exemplář (Die vorgeschichtliche Denkmalpflege in Mähren) zaslaný Úřadu říšského protektora (s průvodním dopisem K. Huckeho Úřadu ř́ŕského protektora z 12. prosince 1941) viz NA, fond Úřad ř́íšsého protektora v Čechách a na Moravě, sign. I-10 V-4-1, karton 536. Kompletní text byl již zveřejněn - viz Blažek 2003, 595-597.

20 Dopis K. Huckeho W. von Bothovi, 20. ledna 1942; NA, fond Úřad říšského protektora $\mathrm{v}$ Čechách a na Moravě, sign. I-10 V-4-1, karton 536.
21 Viz dopis K. Schwabeho ř́šskému protektorovi v Čechách a na Moravě, 2. ledna 1942 (s opisem Huckeho koncepce Die vorgeschichtliche Denkmalpflege in Mähren); NA, fond Úřad ř́š́ského protektora v Čechách a na Moravě, sign. I-10 V-5-1, karton 538. Dopis adresovaný ministerstvu školství a národní osvěty není k dispozici.

22 Dopis K. Huckeho W. von Bothovi, 20. ledna 1942; NA, fond Úřad ř́išského protektora $\mathrm{v}$ Čechách a na Moravě, sign. I-10 V-4-1, karton 536.

23 Dopis W. von Botha K. Huckemu, 23. ledna 1942 (koncept); NA, fond Úřad říšského protektora v Čechách a na Moravě, sign. I-10 V-4-1, karton 536.

24 Dopis Úřadu říšského protektora (K. von Burgsdorff) ministerstvu školství a národní osvěty (F. Kraus), 26. ledna 1942 (koncept); NA, fond Úřad ř́šského protektora v Čechách a na Moravě, sign. I-10 V-4-1, karton 536.

25 Dopis J. Kaprase Památkovému úřadu v Praze, 8. srpna 1941; NA, fond Státní památková správa, karton 650, spis čj. 5986/1941.

26 Camilla Streitová nastoupila do Archeologického ústavu 1. srpna 1941 s úkolem zastupovat německé zájmy. Zástupkyní ředitele Jaroslava Böhma se stala oficiálně teprve 2. prosince 1941. Viz dopis ministerstva školství a národní osvěty C. Streitové, 2. prosince 1941; MÚA AV ČR, fond Státní archeologický ústav, karton 3, inv. č. 27 (osobní spis C. Streitové). Viz též Anonymus 1942c.

27 Dopis W. Sieverse K. Schwabemu, 13. června 1942 (opis opisu); NA, fond Úřad říšského protektora v Čechách a na Moravě, sign. 114-197/2, karton 195 (nezpracovaná část). Podpora Huckeho záměru ze strany Ahnenerbe mj. souvisela s komplikovaným vztahem mezi Ahnenerbe a Zotzem. Lothar Zotz patřil k okruhu spolupracovníků Ahnenerbe, avšak nikdy se nestal jeho členem. Z hlediska chronologického kontextu je podle mého soudu podstatné, že v prvních měsících roku 1942 (resp. v březnu 1942) se Ahnenerbe zřejmě přímo podílelo na pokusu o Zotzovu diskreditaci, kdy přišlo na přetřes mj. bývalé manželství jeho sekretářky Anny Mickové s Arnoldem Löwensteinem, který byl židovského původu (Reinhard 2008, 106-107; Hlava 2019, 77-78, pozn. 14-16). V Huckeho př́chodu do Brna však Ahnenerbe rozhodně nehrálo podstatnou (resp. aktivní) roli, avšak Hucke byl na Moravě nepochybně jeho exponentem, nikoliv ale primárně proti Zotzovi (srov. ovšem opačně Kater 1974, 271-272; Mahsarski 2011, 230).

28 K jednání mezi von Bothem a Schwabem viz dopis W. von Botha K. H. Frankovi, 24. června 1942; NA, fond Úřad ř́išského protektora v Čechách a na Moravě, sign. I-10 V-5-1, karton 538.

29 Dopis K. Huckeho W. von Bothovi, 18. června 1942; NA, fond Ưřad říšského protektora v Čechách a na Moravě, sign. 114-197/2, karton 195 (nezpracovaná část).

30 Dopis W. von Botha K. Huckemu, 24. června 1942 (kopie); NA, fond Úřad říšského protektora $v$ Čechách a na Moravě, sign. I-10 V-5-1, karton 538.

31 Dopis W. von Botha K. H. Frankovi, 24. června 1942; NA, fond Úřad ř́išského protektora v Čechách a na Moravě, sign. I-10 V-5-1, karton 538.

32 Viz souhlasné poznámky H. Heckela (z 24. června 1942) a dr. Fuchse (z 4. července 1942) na dopisu W. von Botha K. H. Frankovi, 24. června 1942; NA, fond Úřad ř́išského protektora v Čechách a na Moravě, sign. I-10 V-5-1, karton 538.

33 Dopis W. von Botha K. Huckemu, 16. července 1942 (kopie); NA, fond Úřad ř́šssého protektora v Čechách a na Moravě, sign. 114-197/2, karton 195 (nezpracovaná část). Upozorněme, že organizační jednotka Úřadu říšského protektora, 
v níž byl zařazen Wolf von Both, byla na počátku července 1942 v rámci reorganizace protektorátní správy přesunuta na ministerstvo školství.

34 Dopis K. H. Franka K. Schwabemu, 22. července 1942 (koncept); NA, fond Úřad říšského protektora v Čechách a na Moravě, sign. I-10 V-5-1, karton 538.

35 Šlo o nedochovaný (?) spis čj. 49301/1942, který je zmiňován v některých následných archiváliích. Viz např. dopis ministerstva školství (W. von Both) odbočce Brno Archeologického ústavu, 25. března 1943 (koncept); NA, fond Ministerstvo školství, karton 3244, inv. č. 1751, spis čj. 28681/1943 (s chybným datováním konstitutivního spisu k 25. červenci 1942). Viz též např. Činnost odbočky od podzimu 1944 do konce roku 1945 (J. Poulík) - př́loha dopisu J. Poulíka J. Böhmovi z 18. dubna 1946; MÚA AV ČR, fond Státní archeologický ústav, karton 10, inv. č. 117.

36 Dopis W. von Botha K. Huckemu, 18. července 1942; NA, fond Úřad říšského protektora v Čechách a na Moravě, sign. 114-197/2, karton 195 (nezpracovaná část).

37 Přípis W. von Botha z 9. října 1942 na kopii dopisu W. von Botha K. Huckemu z 18. července 1942; NA, fond Úřad ř́ŕšského protektora v Čechách a na Moravě, sign. 114-197/2, karton 195 (nezpracovaná část) („Am 8/10 sind wir Fragen der Aussenstelle zu allg. Zufriedenheit geklärt werden."). Viz též dopis K. Huckeho W. von Bothovi, 2. července 1943; NA, fond Úřad ř́šského protektora v Čechách a na Moravě, sign. I-10 V-5-1, karton 538 [„,die Unterredung (...), in der Sie mir - es war an einem Nachmittag während der Tagung des Forschungsrates im Jahre 1942 - abschließend den Antrag gaben, die Außenstelle nach dem Muster des Denkmalamtes in Brünn einzurichten."].

38 Dopis K. Huckeho W. von Bothovi, 20. ř́jna 1942; NA, fond Úřad říšského protektora $\mathrm{v}$ Čechách a na Moravě, sign. I-10 V-5-1, karton 538.

39 Počátek činnosti brněnské odbočky teprve v ř́ijnu 1942 zmínil také Wolf von Both v jednom z úředních dopisů - viz dopis W. von Botha K. Huckemu, 15. února 1943 (kopie); NA, fond Úřad říšského protektora v Čechách a na Moravě, sign. 114-197/2, karton 195 (nezpracovaná část) („Die Aufwandsentschädigung für die Leitung der Aussenstelle Brünn der Anstalt für Vor- und Frühgeschichte wird Ihnen vom Oktober v. J. an ausgezahlt werden, da die Aussenstelle erst im Oktober ins Leben getreten ist.").

40 Dopis K. Huckeho ministerstvu školství, 20. ř́ijna 1942; NA, fond Ministerstvo školství, karton 3244, inv. č. 1751, spis čj. 116134/1942.

41 Dopis J. Böhma ministerstvu školství, 6. února 1943 + Kassabuch. Anstalt für Vor- und Frühgeschichte, Aussenstelle Brünn; NA, fond Ministerstvo školství, karton 3244, inv. č. 1751, spis čj. 13254/1943.

42 Viz př́slušné vyúčtování služební cesty - archiv Archeologického ústavu AV ČR, Brno (archiv ARÚB), fond Spisový archiv, krabice U, složka U5 (rok 1942, účet č. 24).

43 Viz dochované účetní doklady s přesnými daty a jmény najatých dělníků (a s podpisy E. Danii) - archiv ARÚB, fond Spisový archiv, krabice U, složka U5 (rok 1942, účet č. 10).

44 K prvním terénním aktivitám v okolí Dambořic viz př́slušné vyúčtování služební cesty - archiv ARÚB, fond Spisový archiv, krabice U, složka U5 (rok 1942, účet č. 18). K datu počátku Poulíkova zaměstnání v brněnské odbočce Archeologického ústavu viz Činnost odbočky od podzimu 1944 do jara 1945 (J. Poulík) - př́ĺloha dopisu J. Poulíka J. Böhmovi z 18. dubna 1946; MÚA AV ČR, fond Státní archeologický ústav, karton 10, inv. č. 117.
45 Personál brněnské odbočky s příslušnými daty viz Činnost odbočky od podzimu 1944 do jara 1945 (J. Poulík) - př́loha dopisu J. Poulíka J. Böhmovi z 18. dubna 1946; MÚA AV ČR, fond Státní archeologický ústav, karton 10, inv. č. 117.

46 Nejpozději na počátku února 1943 byla Huckeho jednotka umístěna v Lipsku. Viz dopis K. Huckeho W. von Bothovi, 6. února 1943; NA, fond Úřad říšského protektora v Čechách a na Moravě, sign. 114-197/2, karton 195 (nezpracovaná část).

47 Viz Činnost odbočky od podzimu 1944 do jara 1945 (J. Poulík) - př́loha dopisu J. Poulíka J. Böhmovi z 18. dubna 1946; MÚA AV ČR, fond Státní archeologický ústav, karton 10, inv. č. 117. S Poulíkovým pověřením přechodným vedením brněnské odbočky Archeologického ústavu mohla souviset jeho cesta do Prahy od 7. do 9. prosince 1942. Ve dnech 8. a 9. prosince 1942 měl totiž na programu výhradně „amtliche Angelegenheiten im Archäol. Institut in Prag“ (viz př́íslušné vyúčtování služební cesty - archiv ARÚB, fond Spisový archiv, krabice U, složka U5, rok 1942, účet č. 47).

48 Pozvání k jednání - viz dopis Úřadu ř́íšského protektora H. Schwabedissenovi (na vědomí C. Streitové), 10. prosince 1942 (koncept); NA, fond Úřad ř́šského protektora v Čechách a na Moravě, sign. I-10 V-5-2, karton 538 (s von Bothovou poznámkou „die Besprechung hat stattgefunden, dr. Schw. wird die Vertretung von Hucke übernommen“).

49 Dopis C. Streitové W. von Bothovi, 21. února 1943 (s přiloženou dopisní obálkou s předtištěným nápisem Amt für Vorgeschichte in Brünn a razítkem z 12. února 1943); NA, fond Ministerstvo školství, karton 3244, inv. č. 1751, spis čj. 8914/1943.

50 Dopis ministerstva školství (W. von Both) odbočce Brno Archeologického ústavu, 3. března 1943 (koncept); NA, fond Ministerstvo školství, karton 3244, inv. č. 1751, spis čj. 8914/1943.

51 Dopis K. Huckeho ministerstvu školství, 13. března 1943; NA, fond Ministerstvo školství, karton 3244, inv. č. 1751, spis čj. 28681/1943 (s von Bothovou poznámkou „nein!“).

52 Dopis ministerstva školství (W. von Both) odbočce Brno Archeologického ústavu, 25. března 1943; NA, fond Ministerstvo školství, karton 3244, inv. č. 1751, spis čj. 28681/1943.

53 Dopis K. Huckeho W. von Bothovi, 2. července 1943; NA, fond Úřad říšského protektora v Čechách a na Moravě, sign. I-10 V-5-1, karton 538.

54 Dopis C. Streitové ministerstvu školství (W. von Both), 6. července 1943; NA, fond Ministerstvo školství, karton 3244, inv. č. 1751, spis čj. 64354/1943.

55 Dopis ministerstva školství (W. von Both) odbočce Brno Archeologického ústavu (H. Schwabedissen), 11. září 1943 (koncept); NA, fond Ministerstvo školství, karton 3244, spis čj. 64354/1943.

56 Dopis H. Schwabedissena ministerstvu školství (W. von Both), 30. ř́ijna 1943; NA, fond Ministerstvo školství, karton 3244, inv. č. 1751, spis čj. 99311/1943.

57 Dopis ministerstva školství (W. von Both) odbočce Brno Archeologického ústavu (H. Schwabedissen), 1. prosince 1943 (koncept); NA, fond Ministerstvo školství, karton 3244, inv. č. 1751, spis čj. 99311/1943.

58 Dopis K. Huckeho ministerstvu školství (W. von Both), 8. prosince 1943; NA, fond Ministerstvo školství, karton 3244, inv. č. 1751, spis čj. 112739/1943.

59 Dopis W. von Botha K. Huckemu (na vědomí H. Schwabedissenovi), 18. ledna 1944 (koncept); NA, fond Úřad říšského protektora v Čechách a na Moravě, sign. I-10 V-5-1, karton 538. 
60 Statut der Aussenstelle Brünn der Anstalt für Vor- und Frühgeschichte in Prag (Entwurf), bez data (opis); NA, fond Úřad ř́šského protektora v Čechách a na Moravě, sign. I-10 V-5-1, karton 538.

61 Dopis C. Streitové K. Huckemu, 28. července 1943 (opis části); NA, fond Úřad ř́íšského protektora v Čechách a na Moravě, sign. I-10 V-5-1, karton 538. Srov. též Huckeho odpověd' - dopis K. Huckeho C. Streitové, 31. července 1943 (opis části); tamtéž. Streitová celou korespondenci ohledně statutu brněnské odbočky poté poskytla von Bothovi - viz dopis C. Streitové W. von Bothovi, 3. srpna 1943; tamtéž.

62 Dopis K. Huckeho W. von Bothovi, 2. července 1943; NA, fond Úřad řŕšského protektora v Čechách a na Moravě, sign. I-10 V-5-1, karton 538 („Kürzlich besuchte mich Herr dr. Schwabedissen in Leipzig“).

63 Dopis K. Huckeho Poštovní spořitelně, pobočce v Brně, 7. února 1944 (opis); NA, fond Úřad ř́išského protektora v Čechách a na Moravě, sign. I-10 V-5-1, karton 538.

64 Dopis W. von Botha K. Huckemu, 22. února 1944 (kopie); NA, fond Úřad ř́šssého protektora $v$ Čechách a na Moravě, sign. I-10 V-5-1, karton 538.

65 Dopis W. von Botha dr. Rotermundovi, 23. června 1943 (kopie); NA, fond Úřad říšského protektora v Čechách a na Moravě, sign. I-10 V-5-2, karton 538 („Dr. Schwabedissen jetzt wieder zur Wehrmacht einberufen ist").

66 Příslušná korespondence je uložena $\mathrm{v} N \mathrm{NA}$, fond Úřad říšského protektora v Čechách a na Moravě, sign. I-10 V-5-2, karton 538.

67 Dopis C. Streitové J. Poulíkovi, 2. března 1944 (opis); NA, fond Úřad říšského protektora v Čechách a na Moravě, sign. I-10 V-5-1, karton 538.

68 Činnost odbočky od podzimu 1944 do jara 1945 (J. Poulík) př́loha dopisu J. Poulíka J. Böhmovi z 18. dubna 1946; MÚA AV ČR, fond Státní archeologický ústav, karton 10, inv. č. 117.

69 Dopis W. von Botha K. Huckemu, 22. února 1944; NA, fond Úřad říšského protektora $v$ Čechách a na Moravě, sign. I-10 V-5-1, karton 538.

70 Dopis K. Huckeho W. von Bothovi, 16. února 1944; NA, fond Úřad řŕšského protektora v Čechách a na Moravě, sign. I-10 V-5-1, karton 538.

71 Dopis O. Kleemanna L. Zotzovi, 11. července 1942; NA, fond Úřad říšského protektora v Čechách a na Moravě, sign. I-10 V-5-1, karton 538.

\section{Literatura}

Anonymus 1942a: Vorgeschichtliche Bodendenkmalpflege in Mähren. Zeitschrift des Mährischen Landesmuseums in Brünn Neue Folge II, 133-134.

Anonymus 1942b: Zřízení brněnské odbočky archeologického ústavu v Praze. Zprávy památkové péče VI, 55.

Anonymus 1942c: Anstalt für Vor- und Frühgeschichte in Prag. Nachrichtenblatt für Deutsche Vorzeit 18, 39.

Blažek, J. 2003: Z dějin Archeologického ústavu za okupace. Archeologické rozhledy LV, 581-601.

Blažek, J., Lutovská, P. 2002: Prameny k dějinám archeologické památkové péče. Vládní nařízení o archeologické památkové péči z roku 1941. Archeologie ve středních Čechách 6, 617-639.

Böhm, J. 1958: Archeologický ústav ČSAV. Založení a vývoj ústavu. Věstník Československé akademie věd 67, 619-623.

Hlava, M. 2017: Jaroslav Böhm a Lothar Zotz. Kapitola z dějin Státního archeologického ústavu. Archeologie ve středních Čechách 21, 17-45.

Hlava, M. 2018: Konstituování Badatelské rady pro pravěk (Forschungsrat für Vorgeschichte). Kapitola z dějin Státního archeologického ústavu. Archeologie ve středních Čechách 22, 7-30.
Hlava, M. 2019: Přelomový rok 1939. Kapitola z dějin Státního archeologického ústavu. Archeologie ve středních Čechách 23, 415-432.

Hlava, M. 2020a: Jednatelé a dopisovatelé Státního archeologického ústavu. Kapitola z dějin Státního archeologického ústavu. Archeologie ve střredních Čechách 24, 15-31.

Hlava, M. 2020b: Říšskoněmečtí prehistorikové v Protektorátu Čechy a Morava. Nahlédnutí za kulisy. Archeologie ve středních Čechách 24, 303-342.

Hlava, M. 2020c: Innocenc Ladislav Červinka ve Státním archeologickém ústavu (1920-1937). In: M. Neumann, J. Mellnerová Šuteková (eds.): Dejiny archeológie. Archeológia $v$ Československu v rokoch 1918-1948. Studia archaeologica et mediaevalia, Tomus XIV. Bratislava: Comenius University, Bratislava, 154-174.

Hlava, M. v tisku: Vznik brněnské odbočky Archeologického ústavu. In: L. Poláček et al.: Jdeme pod povrch. Př́běhy Archeologického ústavu Akademie věd ČR v Brně. 1920 - 1970 - 2020. Brno: Archeologický ústav AV ČR, Brno, v. v. i.

Kater, M. H. 1974: Das »Ahnenerbe« der SS 1935-1945. Ein Beitrag zur Kulturpolitik des Dritten Reiches. Studien zur Zeitgeschichte. Stuttgart: Deutsche Verlags-Anstalt.

Mahsarski, D. 2011: Herbert Jankuhn (1905-1990). Ein deutscher Prähistoriker zwischen nationalsozialistischer Ideologie und wissenschaftlicher Objektivität. Internationale Archäologie, Band 114. Rahden/Westf: Marie Leidorf.

Maříková-Kubková, J. 2019: 1942. Úsvit moravské slávy. In: M. Kuna, M. Starcová, J. Mař́íková-Kubková (eds.): Sto let v archeologii. Objevy, nálezy a expedice Archeologického ústavu v Praze v letech 1919-2019. Praha: Academia.

Mohn, V. 2018: Nacistická kulturní politika v Protektorátu. Koncepce, praxe a reakce české strany. Praha: Prostor.

Neumann, M. 2019: Rok 1939 v slovenskej archeológii. Musaica archaeologica 4(2), 7-25.

Oliva, M., Kostrhun, P. 2019: Česká archeologie pod jhem nacismu ve světle interetnických vztahů. Archeologické rozhledy LXXI, 105-137.

Pape, W. 2002: Zur Entwicklung des Faches Ur- und Frühgeschichte in Deutschland bis 1945. In: A. Leube (Hrsg.): Prähistorie und Nationalsozialismus. Die mittel- und osteuropäische Ur-und Frühgeschichtsforschung in den Jahren 1933-1945. Studien zur Wissenschafts- und Universitätsgeschichte, Band 2. Heidelberg: Synchron Verlag, 163-226.

Rataj, J., Šolle, M., Vencl, S. 2003: Vzpomínky pracovníků Státního archeologického ústavu v Praze. Archeologické rozhledy LV, 139-165.

Reinhard, J. 2008: Dr. Werner Mähling - zur Biographie eines „deutschen“ Prähistorikers. In: A. Hanöffner, V. Schoenenberg, L. Siftar, M. Strotz (Hrsg.): Connaissez-vous un dolmen ...? Festschrift für Wolfgang Pape. Freiburg: Janus-Verlag, 103-111.

Sklenář, K. 2011: Vývoj péče o archeologické památky v českých zemích do roku 1989 (1.). Sborník Národního muzea. Řada A - Historie 65, 1-106.

Starcová, M. 2020: Jan Eisner a jeho působení na Slovensku v letech 1920-1939. In: M. Neumann, J. Mellnerová Šuteková (eds.): Dejiny archeológie. Archeológia v Československu v rokoch 1918-1948. Studia archaeologica et mediaevalia, Tomus XIV. Bratislava: Comenius University, Bratislava, 133-153.

Zotz, L. 1942: Die erste Tagung des Forschungsrates für Vorgeschichte. Altböhmen und Altmähren 2, 135-153.

\section{Summary}

The independent Institute of Archaeology in Brno was established in 1970 although its origins as an organisation go back another three decades. As a matter of fact, it was a direct descendant of the Brno branch of the Institute of Archaeology in Prague, 
a de facto detached institution with some autonomy established in the summer of 1942 as a Brno branch (Aussenstelle Brünn) of the then Institute of Archaeology (Anstalt für Vor- und Frïhgeschichte) founded in 1919 as the State Archaeological Institute.

The foundation of the Brno branch of the Institute of Archaeology in the middle of WW2 in 1942 happened in the course of the events taking place in the archaeological research of the Czech lands as a result of the political and administrative transformations of 1938 and 1939. When the Protectorate of Bohemia and Moravia with some alleged (though obviously entirely illusory) autonomy was established at the will of the German Reich in mid-March of 1939 it became clear that local Czech research and cultural institutions would not be spared of far-reaching transformations. Archaeology and its organisational structures were no exception and the archaeological research previously carried out by ethnic Czechs immediately became the subject of interest for the Reichsdeutsche archaeologists.

The discussions about the most appropriate approach were held during the first weeks after the establishment of the Protectorate. The main role in them was played by the officials of the Reich ministry of Research, Education, and Culture in Berlin joined from mid-April 1939 by the staffers the Reichsprotektor office in Prague. Already by late spring of 1939, the general plan was outlined in its basic points. Three basic principles and/or objectives were stipulated: (1) the central research institution for the Reichsdeutsch prehistorians in the Protectorate of Bohemia and Moravia was to become the University, as was common in the Reich; (2) the three leading archaeological institutions staffed with ethnic Czechs - the State Archaeological Institute, the National Museum, and the Moravian Museum - were given German vice-directors (i.e. not directors themselves) in order to gain control over their activities and to focus their research and propaganda capacities most efficiently; (3) both the field and theoretical research was supposed to concentrate on Germanic antiquities. Therefore, the objective was not to dismantle the existing structures and institutions but to gain dominance over them and to steer their activity with the smallest necessary expenses.

The new overlords dedicated special attention to the State Archaeological Institute, which in the pre-war Czechoslovakia enjoyed the exclusive status of a pure research institution. Under the Protectorate, it was re-profiled to carry out rescue excavations following the proved and tested model from various parts of the Reich.

The German plan of unitary implementation of the above-outlined principles was disrupted from the very start by changes taking place in the Moravian Museum. Its Czech director Jaroslav Helfert was removed by the Gestapo at the initiative of local Germans and replaced by a commissioner Josef Freising, one of German patriotic local historians. The action was a revenge for the events from 1918 during which the German influence in the Museum was eliminated and in which Helfert had been significantly involved.

The information about the events in Brno only reached the Reichsprotektor office in Prague in early June of 1939 and was met with considerable unease. In addition, Freising's amateurish behaviour in his new job was criticised by (not only) German officials and it was thus decided in Prague to replace him with a qualified substitute. At first, the possibility of installing an ethnicly Czech director with a German deputy was discussed but it was soon decided that for prestige reasons the directorship would be kept in German hands. The selection of the most fitting candidate took some time since - given the nature of the collection - he was supposed to be educated in both Prehistory and the natural sciences. In the end, the chosen candidate was Karl Hucke, a prehistorian from the Breslau Landesamt für Vorgeschichte (Fig. 1, 2). However, since he had joined the Wehrmacht as a volunteer at the outbreak of WW2, he was only able to take over the direction of the Moravian Museum in November of 1941 after being given a temporary furlough from his service.

Shortly after his arrival at Brno, Hucke attempted to take over authority over the archaeological heritage protection in Moravia from the Institute of Archaeology in Prague. In his motion from December of 1941, he proposed transferring the competence of the Institute of Archaeology to the Department of Prehistory of the Moravian Museum (Fig. 3). However, the Reichsprotektor office, which had the final say in the matter, had no interest in decentralisation of archaeological heritage protection and Hucke's proposal thus ended up being substantially reworked. Based on a proposition of Wolf von Both, a Reichsprotektor office staffer, the Brno branch of the Institute of Archaeology was established in the summer of 1942 as its de facto detached branch with some autonomy. Its establishment was therefore a compromise between Hucke's effort to gain administrative authority over archaeological heritage protection in the region in which he was supposed to work and the centralising principles of the Reichsprotektor office.

Therefore, the intention to establish the Brno branch of the Institute of Archaeology did not arise in the Prague central institution based on its internal needs. The preserved (and so-far identified) archival evidence does not record any participation of ethnically Czech archaeologists in the discussions concerning the decentralisation of either the institution (which de facto occurred as a result of the establishment of its Brno branch) or of archaeological heritage protection in general - even Jaroslav Böhm, as the Institute's director, was apparently never involved in the discussions.

The actual architect of the idea of the Brno branch of the Institute of Archaeology was without any doubt Wolf von Both, employed in the Reichsprotektor office from the spring of 1941 as a minor staffer with Protectorate archaeology on his agenda although his principal professional interest were library studies - with a slight exaggeration we could say that the present-day Institute of Archaeology in Brno owes its existence mainly to a Berlin librarian clerk (for von Both's professional interests, cf. Mohn 2018, 272).

Hucke's effort for securing his independence from the Prague Institute cannot be considered as any form of regional patriotism. He very simply strove to acquire the authority and independence necessary for him to control the region in which he was supposed to carry out his work. After all, he did not give up his effort to gain autonomy even after the foundation of the Institute's Brno branch. From his point of view, the degree of decentralisation was not sufficient (Fig. 4). The repeated conflicts caused by Hucke's obstinacy are just one of many examples of the complex relations between the Reichsdeutsche archaeologists active in the Protectorate as well as between them and the local German authorities. Devoid of any ideological backdrop (cf. a very precise characterisation in Oliva, Kostrhun 2019, 129-130) these conflicts often caused personal antipathies, mutual distrust, and an unwillingness to cooperate. For these reasons, some of the Reichsdeutsche archaeologists preferred working with ethnically Czech prehistorians behind the backs of their German colleagues even though it violated the principles they were supposed to follow. Along these lines, the decent relations between Lothar Zotz and Jaroslav Böhm lead to their silent alliance against Camilla Streit beginning in 1942 (cf. in detail, Hlava 2018, 537-541, 549-552). A similar case will be that of Hucke nominating Josef Poulík in 
February 1944 to be the authorised signatory for financial operations by which he deprived Hermann Schwabedissen of this privilege.

The creation of the Brno branch of the Institute of Archaeology in 1942 was a rational and well-executed act, similarly to the Government's decree on archaeological heritage from the previous year. It was not by accident that both survived the tumultuous changes of 1945 and seamlessly transitioned to the following period.

English translation by Jan Kysela

\section{Kontakt}

Miloš Hlava

Filozofická fakulta, Katedra historie - Sekce archeologie Univerzita Palackého v Olomouci

Křrižkovského 10

CZ-771 80 Olomouc

mihlava@seznam.cz 